\title{
Vitamin D and public health: an overview of recent research on common diseases and mortality in adulthood
}

\author{
Robert Scragg* \\ School of Population Health, University of Auckland, Private Bag 92019, Auckland 1142, New Zealand
}

Submitted 14 April 2011: Accepted 24 May 2011: First published online 23 June 2011

\begin{abstract}
Objective: There is increasing interest in vitamin D and its possible health effects. The aims of the present overview are to summarise the research on common diseases for which there is substantial evidence on vitamin D, identify diseases where vitamin D may be beneficial and discuss the public health implications of these findings.

Design: Literature search of PubMed for the years 2000 to 2010 to identify cohort studies with baseline measures of 25-hydroxyvitamin D (25(OH)D) and randomised controlled trials (RCT) of vitamin D supplementation in relation to fractures, colorectal cancer, CVD and all-cause mortality. Risk ratios of disease from comparisons between $25(\mathrm{OH}) \mathrm{D}$ quantiles in these studies were summarised using RevMan software version 5·1 (The Nordic Cochrane Centre, Copenhagen). Setting: Community-based samples recruited into cohort studies from many countries. Subjects: Older men and women, mostly above 50 years of age.

Results: When comparing the lowest $25(\mathrm{OH}) \mathrm{D}$ category with the highest (or reference), the pooled risk ratio $(95 \% \mathrm{CI})$ was: $1.34(1 \cdot 13,1.59)$ for fractures from nine studies; $1.59(1 \cdot 30,1 \cdot 95)$ for colorectal cancer from nine studies; $1.35(1 \cdot 17,1 \cdot 56)$ for CVD from twelve studies; and $1.42(1.23,1.63)$ for all-cause mortality from twelve studies.

Conclusions: Cohort studies show that baseline $25(\mathrm{OH}) \mathrm{D}$ levels predict increased risk of fractures, colorectal cancer, CVD and all-cause mortality. These associations are weak and could be explained by confounding variables such as obesity and physical activity. Because of their potential public health significance, RCT using vitamin D doses $\geq 50 \mu \mathrm{g} / \mathrm{d}$ are required to determine whether vitamin D protects against these diseases.
\end{abstract}

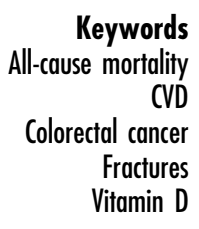

During the last decade vitamin D has emerged from the shadow of other nutrients to centre stage. This trend has been driven by a combination of factors including recent disappointing negative findings from supplementation trials of other vitamins ${ }^{(1)}$, some of which have shown harm $^{(2)}$, and the evidence of pleiotropic effects of vitamin D on many body tissues ${ }^{(3)}$. A further development has been the report from the US Institute of Medicine (IOM) revising slightly higher the recommended daily intake of vitamin $\mathrm{D}^{(4)}$, which has received a mixed response from researchers and clinicians ${ }^{(5,6)}$. The accumulating evidence, much of which was ignored by the IOM because of its observational nature, has reached tipping point for a number of disease outcomes, such that randomised controlled trials (RCT) are required urgently to provide certainty about the possible health benefits from vitamin D.

The aims of the present overview are to summarise the research on common diseases for which there is substantial evidence on vitamin D and identify diseases where vitamin D may be beneficial. The focus is on communitybased studies of free-living people, rather than studies of clinic-based patients or laboratory-based animals, which are cited only to understand possible biological mechanisms; and on vitamin D itself, rather than the active metabolite calcitriol and other analogues of active vitamin D. Such evidence is required to support the introduction of public health programmes to increase the vitamin D status of the general population, which, surely, should be our ultimate aim, should vitamin D be shown by RCT to be beneficial.

\section{Study design and causation}

The quality of the evidence used to decide whether vitamin $\mathrm{D}$ is beneficial depends on study design. At the lowest rung sit ecological studies, which examine associations between exposure (e.g. vitamin D status) and disease at the group level. Typically, comparisons of these measures are made for populations living in towns, cities, counties or countries. These studies are typically used to generate rather than test hypotheses, since the association between exposure and disease is not made at the individual level. The latter studies, where exposure and disease status are measured in individuals, are termed 
analytic and are categorised into two main groups: (i) experimental studies, such as RCT, where the exposure is actively changed by the researchers; and (ii) observational studies, where the researchers only observe and measure exposure.

Epidemiologists typically use the following hierarchy, in descending order of importance, to decide on causation when comparing results from different analytical study designs: (i) experimental studies (i.e. RCT) provide the strongest evidence, since the exposure is actively modified by researchers; (ii) cohort studies (including nested case-control studies) are next, since measurement of exposure precedes disease onset; and (iii) case-control and cross-sectional studies are lowest, since measurement of exposure may be affected by the disease process or biased after disease onset.

\section{Vitamin $D$ status}

Vitamin D occurs in the human body in two forms, either as: (i) cholecalciferol (vitamin $\mathrm{D}_{3}$ ) from sun exposure or eating animal foods; or (ii) ergocalciferol (vitamin $\mathrm{D}_{2}$ ) from mushrooms and yeast irradiated with UV light ${ }^{(7)}$. The sun is the major source of vitamin D in most land animals including man, and vitamin $\mathrm{D}_{3}$ is synthesised in the skin by UV-B radiation activating its precursor 7-dehydrocholesterol ${ }^{(7)}$; although dietary sources of vitamin D can also be important, particularly in people who take vitamin D supplements ${ }^{(8)}$. Vitamin D from both sources then circulates in the blood to the liver where it is converted to its main metabolite, 25-hydroxyvitamin D (25(OH)D), which has blood levels about 1000 times higher than the active metabolite, 1,25-dihydroxyvitamin $\mathrm{D}\left(1,25-(\mathrm{OH})_{2} \mathrm{D}\right)$. Until recently, it was thought that the conversion to $1,25-(\mathrm{OH})_{2} \mathrm{D}$ occurred only in the kidneys, but there is now overwhelming evidence, originally from laboratory cancer research ${ }^{(9)}$, that the cells of most organs have the vitamin $\mathrm{D}$ receptor and, along with this, the capacity to synthesise $1,25-(\mathrm{OH})_{2} \mathrm{D}$ locally - the so-called autocrine or paracrine synthesis of the active metabolite ${ }^{(3,10)}$. The autocrine synthesis of $1,25-(\mathrm{OH})_{2} \mathrm{D}$ is dependent on circulating levels of $25(\mathrm{OH}) \mathrm{D}$. The main marker of vitamin D status is $25(\mathrm{OH}) \mathrm{D}$, which provides a better assessment of vitamin D status than dietary methods since most vitamin D comes from sun exposure ${ }^{(11,12)}$. Objective laboratory measurements of blood vitamin D levels are likely to be less biased than measurement of dietary vitamin D intake using subjective questionnaire methods. Thus, cohort studies which associate $25(\mathrm{OH}) \mathrm{D}$ levels at baseline with subsequent disease risk provide the strongest evidence of causation next to that from RCT of vitamin D supplementation.

\section{Vitamin $D$ and disease}

Vitamin D has been linked to a very wide range of diseases, but sufficient evidence from epidemiological studies has now emerged for the following diseases: fractures, cancer, CVD (including hypertension and type 2 diabetes), and diseases from altered immune function. The evidence for each is discussed in turn, with the focus on cohort studies of non-clinic selected samples with baseline blood measures of $25(\mathrm{OH}) \mathrm{D}$ and RCT of vitamin D supplementation.

\section{Methods}

To identify relevant articles for each of these disease groups, PubMed was searched for the years 2000 to 2010 (19 March 2011) using the term 'vitamin D' with the following keywords: 'fractures' or 'osteoporosis' (number of publications $=2161)$; 'cancer' $(=2031)$; 'infection' or 'cytokines' for immune function $(=955)$; and 'cardiovascular disease' (=736). The annual number of publications in each of these four disease categories during 2000-2010 is shown in Fig. 1. Cohort studies and RCT were identified

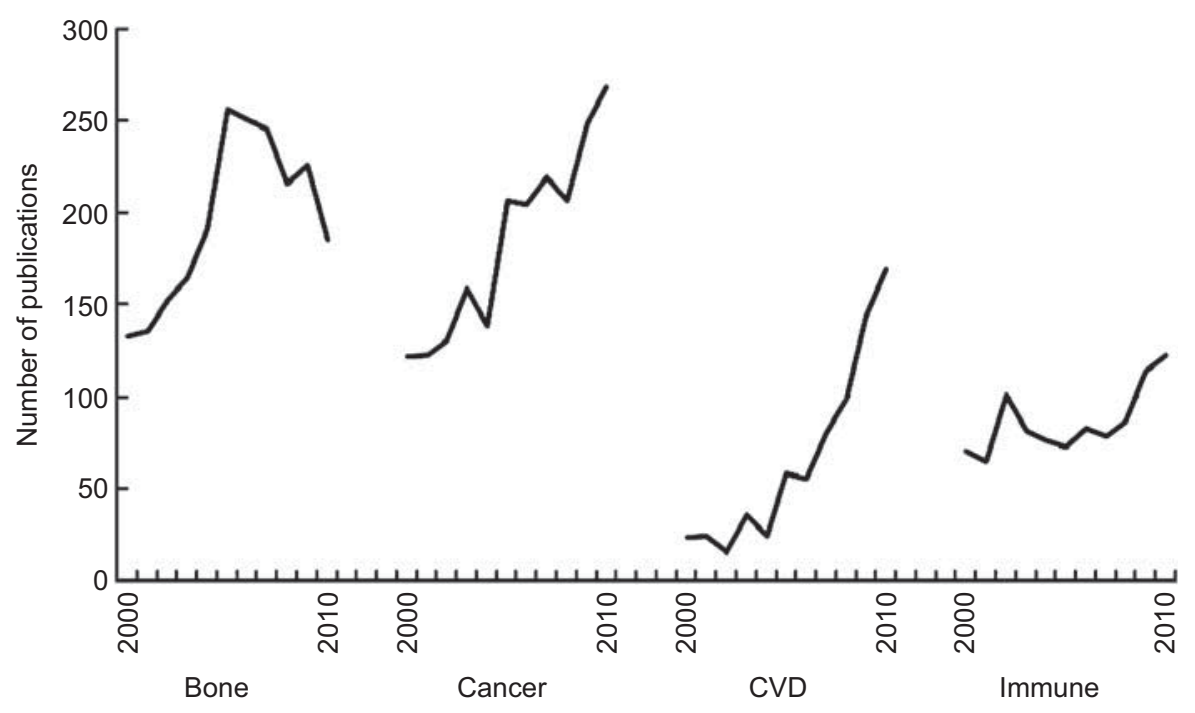

Fig. 1 Trends in vitamin D publications, by disease group, 2000 to 2010 
by searching the abstracts of these publications, and recent reviews and meta-analyses were searched to identify studies published before 2000. The inclusion criteria for cohort studies (including nested case-control studies) were: (i) study samples recruited from community or occupational groups (patient samples were excluded); and (ii) baseline vitamin D status assessed using blood measures of 25(OH)D (studies of dietary vitamin D status were excluded). Many of the cohort studies of CVD also reported on all-cause mortality, so this has been added as an additional outcome in the overview. Eligible cohort studies are summarised in Tables 1-3 for fractures ( $n$ 9), colorectal cancer ( $n$ 10), CVD ( $n$ 13) and all-cause mortality ( $n$ 12).

Measures of effect (relative risks, odds ratios and hazard ratios) associated with quantiles of $25(\mathrm{OH}) \mathrm{D}$ were extracted from identified cohort studies and summarised with RevMan software version $5 \cdot 1$ (The Nordic Cochrane Centre, Copenhagen), using a random effects model with weighting by the inverse variance method and the $I^{2}$ test to assess heterogeneity ${ }^{(13)}$. This approach of summarising effect measures from 25(OH)D quantiles has been used in previous meta-analyses ${ }^{(14,15)}$. The main advantages of this approach are that: (i) non-linear associations can be evaluated (this issue is discussed later with regard to the IOM report and the public health implications of current research); and (ii) any effect from variation between different methods for measuring $25(\mathrm{OH}) \mathrm{D}$ is minimised as the relative risks come from comparisons of participants tested with the same assay within each study. However, the main disadvantage is that the cut-off points used to define $25(\mathrm{OH}) \mathrm{D}$ categories vary between studies, which may have resulted in attenuation of effect because of measurement error. Further, the cut-off points in many studies have been below the range of $80-100 \mathrm{nmol} / \mathrm{l}$ associated with optimum health outcomes ${ }^{(16)}$, which also will have resulted in underestimation of the maximum effect measure. Thus, the summary measures of effect in the present report probably underestimate the full effects associated with variations in $25(\mathrm{OH}) \mathrm{D}$ across the normal population range.

\section{Fractures}

Recognition of the role of vitamin D deficiency in causing bone disease extends back to the 1920s, from the classic studies showing that vitamin D supplementation cured rickets $^{(17)}$. Evidence that vitamin D deficiency might have a causal role in fractures first came from UK studies carried out in the 1970s which showed that osteomalacia ('adult rickets') was common in patients with hip fracture $^{(18)}$ and more common after winter (February-April) than in other months of the year ${ }^{(19)}$. Following this, numerous (at least thirty) case-control studies were carried out which collectively showed that hip-fracture cases had lower 25(OH)D levels than controls ${ }^{(20)}$.

The usual sequence is for cohort studies to be carried out after case-control studies, before progressing to RCT. However, for fractures, the RCT were started first, partly driven by pharmaceutical companies with a commercial interest, seeking to show that the active metabolite (calcitriol) and its analogues (alphacalcidol) might reduce the risk of fractures. At least twenty-five studies of active vitamin D have been carried out, extending back to the 1980s; with meta-analyses of these showing that active vitamin D reduces the incidence of fractures, but increases the incidence of hypercalcaemia ${ }^{(21-23)}$. This latter finding, combined with the high cost of active vitamin $\mathrm{D}$, which needs to be taken daily because of its short half-life, make these medications unsuitable for population-based fracture prevention programmes.

At least twenty-four RCT have been carried out using vitamin D (alone or with $\mathrm{Ca})^{(23)}$, beginning with the first one from France published in $1992^{(24)}$ and continuing to the most recent in 2010 from Australia and Finland ${ }^{(25,26)}$. These RCT have two widely accepted limitations. First, the daily dose in many of these studies (average about $12.5 \mu \mathrm{g} / \mathrm{d}$ ) is now considered too low as it would raise $25(\mathrm{OH}) \mathrm{D}$ levels only by $10-15 \mathrm{nmol} / \mathrm{l}^{(27)}$. Current recommendations are that at least $42.5 \mu \mathrm{g} / \mathrm{d}$ is required to increase $25(\mathrm{OH}) \mathrm{D}$ levels up to those associated with optimum health $(80 \mathrm{nmol} / \mathrm{l})^{(28)}$. Second, many of these RCT gave Ca in combination with vitamin D, and usually with higher doses of vitamin D $(17 \cdot 5-20 \mu \mathrm{g} / \mathrm{d})$ compared with studies that gave vitamin D by itself $(10 \mu \mathrm{g} / \mathrm{d})$. Thus, it is not possible to conclude whether any beneficial effect on fracture incidence is from vitamin $\mathrm{D}$ by itself. Hence the inconsistent findings from recent meta-analyses, with some concluding that vitamin $\mathrm{D}$ is beneficial against fractures only when combined with $\mathrm{Ca}^{(23,29,30)}$ and others concluding that vitamin $\mathrm{D}$ taken in higher doses $(>17 \cdot 5 \mu \mathrm{g} / \mathrm{d})$ is effective by itself $^{(31-34)}$, while yet another concluded that Ca supplementation by itself had no effect on fracture incidence ${ }^{(35)}$. The eventual outcome of this debate has important implications for any future public health prevention strategies, should future research show that vitamin D (with or without $\mathrm{Ca}$ ) is beneficial (see public health implications below).

The inconclusive results from RCT of vitamin D supplementation increase the importance of evidence from cohort studies comparing baseline $25(\mathrm{OH}) \mathrm{D}$ levels with subsequent risk of fracture. At least ten of these cohort studies have been published, beginning with a very small study in 1990 (in which nine participants had fractures during 30-month follow-up) which is not included in the summary analysis since its sample of older adults was recruited from sheltered housing and not the general community ${ }^{(36)}$. The first community-based study was published in $1998^{(37)}$, and the rest since $2005^{(38-45)}$. The main outcomes examined have been hip and non-vertebral fractures (Table 1). The pooled relative risk is 1.34 (95\% CI $1 \cdot 13,1.59)$ comparing the lowest $25(\mathrm{OH}) \mathrm{D}$ quantile with the higher reference category in each study (Fig. 2), indicating a weak effect associated with low vitamin D status. The possibility of residual confounding remains as 
Table 1 Relative risk of having a fracture associated with low baseline level of 25-hydroxyvitamin $D(25(O H) D)$ in cohort studies

\begin{tabular}{|c|c|c|c|c|c|}
\hline $\begin{array}{l}\text { Publication (source in cited } \\
\text { publication) }\end{array}$ & Sample & $\begin{array}{l}\text { Type of fracture } \\
\text { (no. with fracture) }\end{array}$ & $\begin{array}{l}\text { 25(OH)D in nmol/l } \\
\text { (quantile) }\end{array}$ & $\mathrm{RR}(95 \% \mathrm{Cl})$ & Adjusted confounders \\
\hline $\begin{array}{l}\text { Cummings et al. }(1998)^{(37)} \\
\quad \text { (Table 2) }\end{array}$ & $\begin{array}{l}\text { Community-living women } \\
\geq 65 \text { years age, followed for } \\
5.9 \text { years }\end{array}$ & Hip (133) & $\begin{array}{l}\leq 47(\mathrm{Q} 1) \\
>47(\mathrm{Q} 2)\end{array}$ & $\begin{array}{l}1 \cdot 2(0 \cdot 7,1 \cdot 9) \\
1 \cdot 0\end{array}$ & Age, weight \\
\hline Gerdhem et al. $(2005)^{(38)}$ & $\begin{array}{l}\text { Population-sampled women aged } \\
75 \text { years, followed for } 3 \text { years }\end{array}$ & All (119) & $\begin{array}{l}<50(\mathrm{Q} 1) \\
\geq 50(\mathrm{Q} 2)\end{array}$ & $\begin{array}{l}2 \cdot 04(1 \cdot 04,4 \cdot 04) \\
1 \cdot 00\end{array}$ & None stated \\
\hline Garnero et al. $(2007)^{(39)}$ & $\begin{array}{l}\text { Employed postmenopausal } \\
\text { women, followed for median } \\
11 \cdot 2 \text { years }\end{array}$ & All (134) & Per SD decrease & $1 \cdot 16(0 \cdot 77,1 \cdot 76)$ & $\begin{array}{l}\text { Age, prevalent fracture, physical } \\
\text { activity }\end{array}$ \\
\hline $\begin{array}{l}\text { Roddam et al. }(2007)^{(40)} \\
\quad \text { (Table 4) }\end{array}$ & $\begin{array}{l}\text { Community-living men and } \\
\text { women } \geq 20 \text { years age, } \\
\text { followed for } 5 \text { years }\end{array}$ & Non-vertebral (730) & $\begin{array}{l}\text { Women: } \\
\quad<50(\mathrm{Q} 1) \\
\quad \geq 100(\mathrm{Q} 4) \\
\text { Men: } \\
\quad<50 \text { (Q1) } \\
\geq 100 \text { (Q4) }\end{array}$ & $\begin{array}{l}\text { Women: } \\
1.06(0.74,1.52)^{\star} \\
1.00 \\
\text { Men: } \\
0.79(0.33,1.92)^{\star} \\
1.00\end{array}$ & $\begin{array}{l}\text { Age, month of blood draw, BMI, } \\
\text { smoking, Ca intake, energy intake, } \\
\text { alcohol, physical activity, marital } \\
\text { status, and (for women) parity, } \\
\text { hormone therapy }\end{array}$ \\
\hline $\begin{array}{l}\text { Cauley et al. }(2008)^{(41)} \\
\text { (Table 2) }\end{array}$ & $\begin{array}{l}\text { Community-living women } \\
50-79 \text { years age, followed for } \\
\text { median } 7 \cdot 1 \text { years }\end{array}$ & Hip (400) & $\begin{array}{l}\leq 47 \cdot 5(\mathrm{Q} 1) \\
\geq 70 \cdot 7(\mathrm{Q} 4)\end{array}$ & $\begin{array}{l}1 \cdot 71(1 \cdot 05,2 \cdot 79) \\
1 \cdot 00\end{array}$ & $\begin{array}{l}\text { Age, BMI, history of fracture, } \\
\text { smoking, alcohol, Ca intake, } \\
\text { steroid use, region }\end{array}$ \\
\hline $\begin{array}{l}\text { Looker \& Mussolino } \\
\qquad(2008)^{(42)} \text { (Table 3) }^{(20}\end{array}$ & $\begin{array}{l}\text { Population-sampled men and } \\
\text { women } \geq 65 \text { years age, } \\
\text { followed from } 1988-94 \text { to } 2000\end{array}$ & Hip (156) & $\begin{array}{l}\leq 42 \cdot 9(\mathrm{Q} 1) \\
\geq 82 \cdot 5(\mathrm{Q} 4)\end{array}$ & $\begin{array}{l}2 \cdot 00(1 \cdot 16,3 \cdot 44)^{\star} \\
1 \cdot 00\end{array}$ & $\begin{array}{l}\text { Age, sex, bone density, BMI, Ca } \\
\text { intake, energy intake, weight loss }\end{array}$ \\
\hline $\begin{array}{l}\text { van Schoor et al. }(2008)^{(43)} \\
\quad \text { (Table 3) }\end{array}$ & $\begin{array}{l}\text { Population-sampled men and } \\
\text { women } \geq 55 \text { years age, } \\
\text { followed for } 6 \text { years }\end{array}$ & Non-vertebral (115) & $\begin{array}{l}<75 \text { years: } \\
<25 \text { (Q1) } \\
\geq 75 \text { (Q4) } \\
\geq 75 \text { years: } \\
<25 \text { (Q1) } \\
\geq 75 \text { (Q4) }\end{array}$ & $\begin{array}{l}<75 \text { years: } \\
3 \cdot 4(0 \cdot 9,12 \cdot 1) \\
1 \cdot 0 \\
\geq 75 \text { years: } \\
0 \cdot 8(0.3,2 \cdot 2) \\
1 \cdot 0\end{array}$ & Age, sex, season \\
\hline $\begin{array}{l}\text { Cauley et al. }(2010)^{(44)} \\
\text { (Table 4) }\end{array}$ & $\begin{array}{l}\text { Community-living men } \geq 65 \text { years } \\
\text { age, followed for mean of } \\
5 \cdot 3 \text { years }\end{array}$ & Non-vertebral (436) & $\begin{array}{l}<47 \text { (Q1) } \\
\geq 70(\mathrm{Q} 4)\end{array}$ & $\begin{array}{l}1 \cdot 21(0 \cdot 96,1 \cdot 65) \\
1 \cdot 00\end{array}$ & $\begin{array}{l}\text { Age, race, clinic, season, physical } \\
\text { activity, height, weight }\end{array}$ \\
\hline $\begin{array}{l}\text { Melhus et al. }(2010)^{(45)} \\
\quad \text { (Table 2) }\end{array}$ & $\begin{array}{l}\text { Population-sampled men, mean } \\
\text { age } 71 \text { years, followed for } \\
\text { median } 11 \text { years }\end{array}$ & All fractures (309) & $\begin{array}{l}<40 \text { (Q1) } \\
>40(\mathrm{Q} 2)\end{array}$ & $\begin{array}{l}1.58(1 \cdot 04,2 \cdot 41) \\
1.00\end{array}$ & $\begin{array}{l}\text { Age, weight, height, season, } \mathrm{Ca} \\
\text { intake, activity, smoking, diabetes } \\
\text { and other chronic diseases }\end{array}$ \\
\hline
\end{tabular}

$\mathrm{RR}$, relative risk.

*Inverse of published relative risk to make highest $25(\mathrm{OH}) \mathrm{D}$ group the reference. 


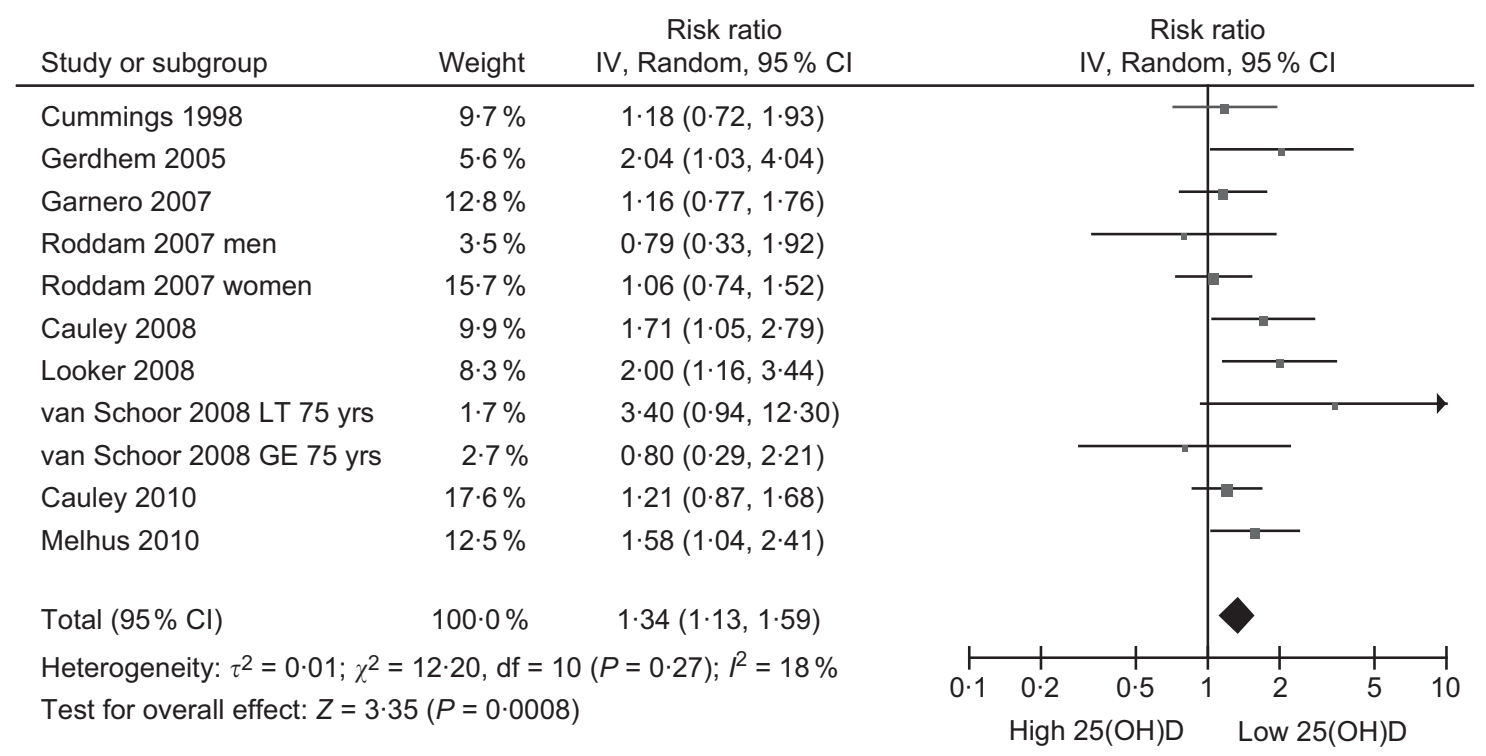

Fig. 2 Forest plot of relative risks of fracture associated with the lowest 25-hydroxyvitamin D $(25(\mathrm{OH}) \mathrm{D})$ category compared with the highest (or reference) in cohort studies

some studies did not control for BMI and physical activity, the two most important confounders (Table 1).

In summary, research on vitamin $\mathrm{D}$ and fractures appears to have lost momentum over the last 5 years, as indicated by the decline in publications during this period (Fig. 1). Conclusions from meta-analyses are inconsistent, because of low doses of vitamin D, often used in combination with $\mathrm{Ca}$. However, the cohort studies indicate that people with low vitamin D levels are at increased risk of suffering fractures (Table 1), but these findings could be explained by other possible confounding factors. RCT giving higher doses of vitamin $\mathrm{D}$ than used previously are required to resolve the current uncertainty.

\section{Cancer}

A possible link between vitamin D and cancer first came from US ecological studies published around 1940 showing that a range of cancers were associated with sunlight exposure and latitude $\mathrm{e}^{(46,47)}$.

However, the modern body of research on this topic is generally considered to have been stimulated by a later ecological study from US researchers who, unaware of the earlier studies, published a paper in 1980 showing an inverse association between latitude and colorectal cancer mortality in the USA ${ }^{(48)}$. Since then, further ecological studies have shown inverse associations between solar radiation and cancers of the breast ${ }^{(49)}$, prostate $e^{(50)}$, ovary ${ }^{(51)}$ and lymphoma ${ }^{(52)}$, suggesting that vitamin $\mathrm{D}$ may protect against a wide range of cancers.

A substantial number of cohort studies, with baseline measures of $25(\mathrm{OH}) \mathrm{D}$, have been carried out to test the hypotheses generated by the above ecological studies. These studies have been reviewed in a recent report by the International Agency for Research on Cancer (IARC) ${ }^{(53)}$, since updated by the same authors ${ }^{(54)}$. Despite the extensive laboratory research showing the anticancer properties of vitamin D in prostate cells ${ }^{(55)}$, the current evidence does not support an association between vitamin $\mathrm{D}$ and prostate cancer risk. Eleven cohort studies of $25(\mathrm{OH}) \mathrm{D}$ and prostate cancer were published up until December 2009, with enough cases ( $n$ 3956) to detect a very small effect ${ }^{(54)}$. However, meta-analyses of these studies show no association between $25(\mathrm{OH}) \mathrm{D}$ and prostate cancer risk ${ }^{(53,54,56)}$. A further recent nested case-control study from Hawaii also found no association between baseline plasma $25(\mathrm{OH}) \mathrm{D}$ and prostate cancer risk ${ }^{(57)}$, confirming the conclusions of the meta-analyses.

The evidence is stronger for breast cancer, with five cohort studies published up until December 2009 and the pooled relative risk being inverse but not statistically significant ${ }^{(54,58)}$. For example, one meta-analysis calculated that a $50 \mathrm{nmol} / \mathrm{l}$ increase in $25(\mathrm{OH}) \mathrm{D}$ was associated with a relative risk of $0.92(95 \% \mathrm{CI} 0.82,1 \cdot 04 ; P=0 \cdot 016)^{(58)}$, which suggests that if vitamin $\mathrm{D}$ is eventually confirmed to protect against breast cancer, the reduction in individual risk could be small. Since these meta-analyses, three further cohort studies of serum 25(OH)D and breast cancer have been published. One study from France reported a significant inverse association between baseline 25(OH)D and subsequent breast cancer risk ${ }^{(59)}$, a Swedish study reported a non-significant inverse association ${ }^{(60)}$, while further follow-up of mortality from the Third National Health and Nutrition Examination Survey (NHANES) cohort also has reported a non-significant inverse association ${ }^{(61)}$. Thus, the overall evidence from cohort studies suggests there may be an inverse association between vitamin $\mathrm{D}$ status and subsequent risk of breast cancer, but further cohort studies are required to confirm this. 
The cancer most strongly linked to vitamin D deficiency is colorectal cancer. To date, there are ten published cohort studies which have examined the association between baseline blood levels of 25(OH)D and incidence of colorectal cancer, beginning with the first report in $1989^{(62)}$ and the rest since the mid-1990s $^{(61,63-70)}$ (Table 2). Nine of these studies have been summarised in a meta-analysis, which found a significantly reduced risk of colorectal cancer with increasing $25(\mathrm{OH}) \mathrm{D}$ levels ${ }^{(54)}$. For a $25 \mathrm{nmol} / 1$ increase in $25(\mathrm{OH}) \mathrm{D}$, colorectal cancer risk was decreased by 15\% (95\% CI 8 , $21 \%)$. An indication of the possible change in risk across the population range of $25(\mathrm{OH}) \mathrm{D}$ is shown in Fig. 3, with the pooled relative risk for people in the lowest $25(\mathrm{OH}) \mathrm{D}$ category being 1.59 compared with the lowest category. This suggests that the strength of the association between vitamin $\mathrm{D}$ and colorectal cancer is weak to moderate. The IARC report concluded that there was a significant inverse association between vitamin D status and colorectal cancer, but considered this to be 'only limited evidence of a causal link due to confounding by other dietary or lifestyle factors' (p. 305) ${ }^{(53)}$. The main possible confounder is physical activity, since this is associated with both colorectal cancer ${ }^{(71)}$ and $25(\mathrm{OH}) \mathrm{D}$ levels ${ }^{(72)}$. Although physical activity was controlled for in several of the studies (Table 3), it is possible that errors in accurately measuring physical activity with questionnaires may have resulted in residual confounding and failure to control fully for its effects in multivariate analyses. Alternatively, it is also possible that any beneficial effect from physical activity could be from increased 25(OH)D levels resulting from activity. Only clinical trials of vitamin D supplementation will resolve this uncertainty.

The main RCT carried out to date to see if vitamin D supplementation reduces incidence of colorectal cancer is the Women's Health Initiative. This study recruited 36282 women aged 50-79 years into the vitamin D/calcium part of the wider study ${ }^{(66)}$. Women in the intervention arm of the study were given $10 \mu \mathrm{g}$ of vitamin D and $1000 \mathrm{mg}$ of Ca to take daily. At the end of the follow-up period (average of 7 years), there was no difference in the incidence of colorectal cancer between treatment and placebo arms. This negative finding could be due to some well-recognised limitations in the study design. These include: (i) too low a dose of vitamin $\mathrm{D}$, which has been estimated to increase $25(\mathrm{OH}) \mathrm{D}$ levels only by about $7 \mathrm{nmol} / \mathrm{l}^{(73)}$; (ii) low compliance with only $70 \%$ of participants taking the study capsules $50 \%$ or more of the time; and (iii) contamination in the control group with many of them continuing to take vitamin D supplements during the follow-up period ${ }^{(74)}$. One other RCT of vitamin D supplementation and cancer has been conducted ${ }^{(75)}$. In that study, 1179 women from Nebraska were given both vitamin D $(27 \cdot 5 \mu \mathrm{g} / \mathrm{d})$ and Ca (1400-1500 mg/d) together, Ca only or placebo. After 4 years' follow-up, women in both treatment arms had about half the risk of any type of cancer compared with those taking placebo, indicating a consistent beneficial effect for $\mathrm{Ca}$. Thus, the role of vitamin $\mathrm{D}$ by itself is still unclear after this study and needs confirmation by other RCT.

The relationship between $25(\mathrm{OH}) \mathrm{D}$ levels and other rarer cancers has also been examined. In analyses pooling data from ten cohort studies, serum 25(OH)D was not associated with any of the following cancers: endometrial, oesophageal, gastric, kidney, non-Hodgkin lymphoma or ovarian; although risk of pancreatic cancer was found to be increased in people with $25(\mathrm{OH}) \mathrm{D}$ levels above $100 \mathrm{nmol} / \mathrm{l}^{(76)}$. However, the latter finding was not confirmed in another US cohort study which reported a significant inverse association between predicted $25(\mathrm{OH}) \mathrm{D}$ level and risk of pancreatic cancer ${ }^{(77)}$. Thus, the evidence on the association between vitamin $\mathrm{D}$ status and pancreatic cancer is inconsistent.

In summary, research on vitamin $\mathrm{D}$ and cancer has strong momentum, as indicated by the continuing increase in the annual number of publications during the last decade (Fig. 1). There is now a large body of laboratory work showing that active vitamin D (including calcitriol and its analogues) has anticancer properties by encouraging cell differentiation and proliferation of cancer cells from a range of tissues ${ }^{(78)}$. The cancer most strongly linked with low vitamin D status is colorectal cancer. However, this research has reached a tipping point, and RCT of vitamin D supplementation are now required to determine whether or not vitamin D protects against this cancer.

\section{CVD}

Research on vitamin D and CVD has increased more rapidly during the last decade than on other diseases (Fig. 1). This increase belies the major changes in scientific opinion about the role of vitamin D in CVD that has taken place over the last 40 years $^{(79)}$. Until the 1970s, it was generally believed by researchers and clinicians that vitamin $\mathrm{D}$ was a cause of atherosclerosis and $\mathrm{CHD}^{(80-84)}$. These conclusions were based on animal studies which used pharmacological doses of vitamin D (125-250 $\mu \mathrm{g} / \mathrm{kg}$ per d) in a cholesterol model to produce arteriosclerosis and on case reports of patients with arterial calcification and hypertension without controls to provide a reference point for vitamin D intake ${ }^{(79)}$. A major step was the development of the assays for measuring blood levels of $25(\mathrm{OH}) \mathrm{D}^{(85)}$, which showed that most vitamin D (>80\%) came from dermal production following sun exposure, not diet ${ }^{(11,12)}$.

Opinions about the role of vitamin D in CVD started to change (by 1980) with the publication of the hypothesis that UV radiation, through vitamin $\mathrm{D}$ formation, may protect against $\mathrm{CVD}^{(86)}$, which was subsequently expan$\mathrm{ded}^{(87)}$; and the identification of a vitamin $\mathrm{D}$ receptor in rat heart ${ }^{(88)}$, along with animal studies showing that vitamin $\mathrm{D}$ affected cardiovascular function ${ }^{(89)}$. The first case-control studies to use the newly developed assay for $25(\mathrm{OH}) \mathrm{D}$ found, unexpectedly at the time, that myocardial infarction cases had similar or lower 25(OH)D levels than controls ${ }^{(90-92)}$. The initial test of the hypothesis 
Table 2 Relative risk of having colorectal cancer associated with low baseline level of 25-hydroxyvitamin D (25(OH)D) in cohort studies

\begin{tabular}{|c|c|c|c|c|c|}
\hline $\begin{array}{l}\text { Publication (source in cited } \\
\text { publication) }\end{array}$ & Sample & No. of cases & $\begin{array}{l}\text { 25(OH)D in nmol/l } \\
\text { (quantile) }\end{array}$ & $\mathrm{RR}(95 \% \mathrm{Cl})$ & Adjusted confounders \\
\hline $\begin{array}{l}\text { Garland et al. (1989) } \\
\text { (Fig. 2) }\end{array}$ & $\begin{array}{l}\text { Community volunteers aged } \\
\geqslant 35 \text { years, surveyed in } 1974 \\
\text { followed up to } 1983\end{array}$ & 34 & $\begin{array}{l}<50(\mathrm{Q} 1) \\
\geq 50(\mathrm{Q} 2)\end{array}$ & $\begin{array}{l}3.3(P<0.05)^{\star} \\
1.0\end{array}$ & $\begin{array}{l}\text { Controls matched for age, sex, race and } \\
\text { month of blood draw }\end{array}$ \\
\hline $\begin{array}{l}\text { Braun et al. }(1995)^{(63)} \\
\quad \text { (Table 1) }\end{array}$ & $\begin{array}{l}\text { Community volunteers aged } \\
\geqslant 35 \text { years, surveyed in } 1974 \\
\text { followed from } 1983 \text { to } 1991\end{array}$ & 57 & $\begin{array}{l}<43(\mathrm{Q} 1) \\
>75(\mathrm{Q} 5)\end{array}$ & $\begin{array}{l}2 \cdot 5(0 \cdot 71,10 \cdot 00)^{*} \\
1 \cdot 0\end{array}$ & $\begin{array}{l}\text { Controls matched for age, sex, race and } \\
\text { month of blood draw }\end{array}$ \\
\hline $\begin{array}{l}\text { Tangrea et al. }(1997)^{(64)} \\
\quad \text { (Table 4) }\end{array}$ & $\begin{array}{l}\text { Cancer-free male smokers aged } \\
50-69 \text { years, followed up to } 8 \text { years }\end{array}$ & 146 & $\begin{array}{l}<24(\mathrm{Q} 1) \\
>48(\mathrm{Q} 4)\end{array}$ & $\begin{array}{l}2 \cdot 7(0 \cdot 9,3 \cdot 0)^{\star} \\
1 \cdot 0\end{array}$ & $\begin{array}{l}\text { Controls matched for age, clinic and } \\
\text { month of blood collection }\end{array}$ \\
\hline $\begin{array}{l}\text { Feskanich et al. }(2004)^{(65)} \\
\text { (Table 2) }\end{array}$ & $\begin{array}{l}\text { Female nurses aged } 43-70 \text { years, } \\
\text { followed up to } 11 \text { years }\end{array}$ & 193 & $\begin{array}{l}\text { Low (Q1) } \\
\text { High (Q5) }\end{array}$ & $\begin{array}{l}1.89(0.96,3.70)^{*} \\
1.00\end{array}$ & $\begin{array}{l}\text { Age, month of blood collection, BMI, } \\
\text { activity, smoking, alcohol, menopause, } \\
\text { hormone therapy, aspirin, family } \\
\text { history of colorectal cancer, intakes of } \\
\text { Ca and red meat }\end{array}$ \\
\hline $\begin{array}{l}\text { Wactawski-Wende } \\
\text { et al. }(2006)^{(66)}(\text { Table 2) }\end{array}$ & $\begin{array}{l}\text { Volunteer women in clinical trial, aged } \\
50-79 \text { years, followed for mean of } \\
7 \text { years }\end{array}$ & 317 & $\begin{array}{l}<31 \cdot 0(\mathrm{Q} 1) \\
\geq 58 \cdot 4(\mathrm{Q} 4)\end{array}$ & $\begin{array}{l}2 \cdot 53(1 \cdot 49,4 \cdot 32) \\
1 \cdot 00\end{array}$ & None \\
\hline $\begin{array}{l}\text { Otani et al. }(2007)^{(67)} \\
\quad \text { (Table 4) }\end{array}$ & $\begin{array}{l}\text { Population-sampled men and women } \\
40-69 \text { years age, followed for } \\
\text { mean of } 11.5 \text { years }\end{array}$ & 375 & $\begin{array}{l}\text { Men: } \\
\quad<57 \text { (Q1) } \\
\geq 80 \text { (Q4) } \\
\text { Women: } \\
\quad<57 \text { (Q1) } \\
\geq 80 \text { (Q4) }\end{array}$ & $\begin{array}{l}\text { Men: } \\
1 \cdot 36(0 \cdot 70,2 \cdot 86)^{\star} \\
1.00 \\
\text { Women: } \\
0 \cdot 90(0 \cdot 40,2 \cdot 00)^{\star} \\
1 \cdot 00\end{array}$ & $\begin{array}{l}\text { Age, sex, date of blood draw, region, } \\
\text { smoking, alcohol, BMI, physical } \\
\text { activity, supplement use, family history } \\
\text { of colorectal cancer }\end{array}$ \\
\hline $\begin{array}{l}\text { Wu et al. }(2007)^{(68)} \\
\quad(\text { Table } 2)\end{array}$ & $\begin{array}{l}\text { Male health professionals mean age } \\
66 \text { years, followed up to } 8 \text { years }\end{array}$ & 179 & $\begin{array}{l}\text { Low (Q1) } \\
\text { High (Q5) }\end{array}$ & $\begin{array}{l}1 \cdot 20(0 \cdot 66,2 \cdot 22)^{*} \\
1 \cdot 00\end{array}$ & $\begin{array}{l}\text { Age, month of blood collection, family } \\
\text { history, aspirin, smoking, alcohol, } \\
\text { physical activity, Ca and meat intakes }\end{array}$ \\
\hline $\begin{array}{l}\text { Freedman et al. }(2010)^{(61)} \\
\quad \text { (Table 4) }\end{array}$ & $\begin{array}{l}\text { Population-sampled men and women } \\
\geq 17 \text { years age, followed from } \\
1988-94 \text { to } 2006\end{array}$ & 95 & $\begin{array}{l}<50(\mathrm{Q} 1) \\
\geq 100(\mathrm{Q} 4)\end{array}$ & $\begin{array}{l}2 \cdot 86(0 \cdot 88,9 \cdot 09)^{*} \\
1 \cdot 00\end{array}$ & Age, sex, race/ethnicity, smoking, BMI \\
\hline $\begin{array}{l}\text { Jenab et al. }(2010)^{(69)} \\
\quad \text { (Table 2) }\end{array}$ & $\begin{array}{l}\text { Men and women, mean age } 58 \text { years, } \\
\text { recruited from community, followed } \\
\text { for mean of } 4 \text { years }\end{array}$ & 1248 & $\begin{array}{l}<25 \text { (Q1) } \\
\geq 50 \text { to }<75(\mathrm{Q} 3 \text { of } 5)\end{array}$ & $\begin{array}{l}1.32(0 \cdot 87,2 \cdot 01) \\
1 \cdot 00\end{array}$ & $\begin{array}{l}\text { Age, sex, study centre, education, BMI, } \\
\text { physical activity, smoking, alcohol, diet } \\
\text { (including meat), and (for women) } \\
\text { menopause, hormone therapy use }\end{array}$ \\
\hline $\begin{array}{l}\text { Woolcott et al. }(2010)^{(70)} \\
\quad(\text { Table 2) }\end{array}$ & $\begin{array}{l}\text { Men and women, } 45-75 \text { years age, } \\
\text { recruited from community, followed } \\
\text { for mean of } 1.7 \text { years }\end{array}$ & 229 & $\begin{array}{l}<42(\mathrm{Q} 1) \\
\geq 82(\mathrm{Q} 5)\end{array}$ & $\begin{array}{l}1.67(0.93,3.03)^{\star} \\
1.00\end{array}$ & $\begin{array}{l}\text { Age, sex, ethnicity, area, date of blood } \\
\text { draw, family history, BMI, meat intake }\end{array}$ \\
\hline
\end{tabular}

${ }^{*}$ Inverse of published relative risk to make highest $25(\mathrm{OH}) \mathrm{D}$ group the reference. 


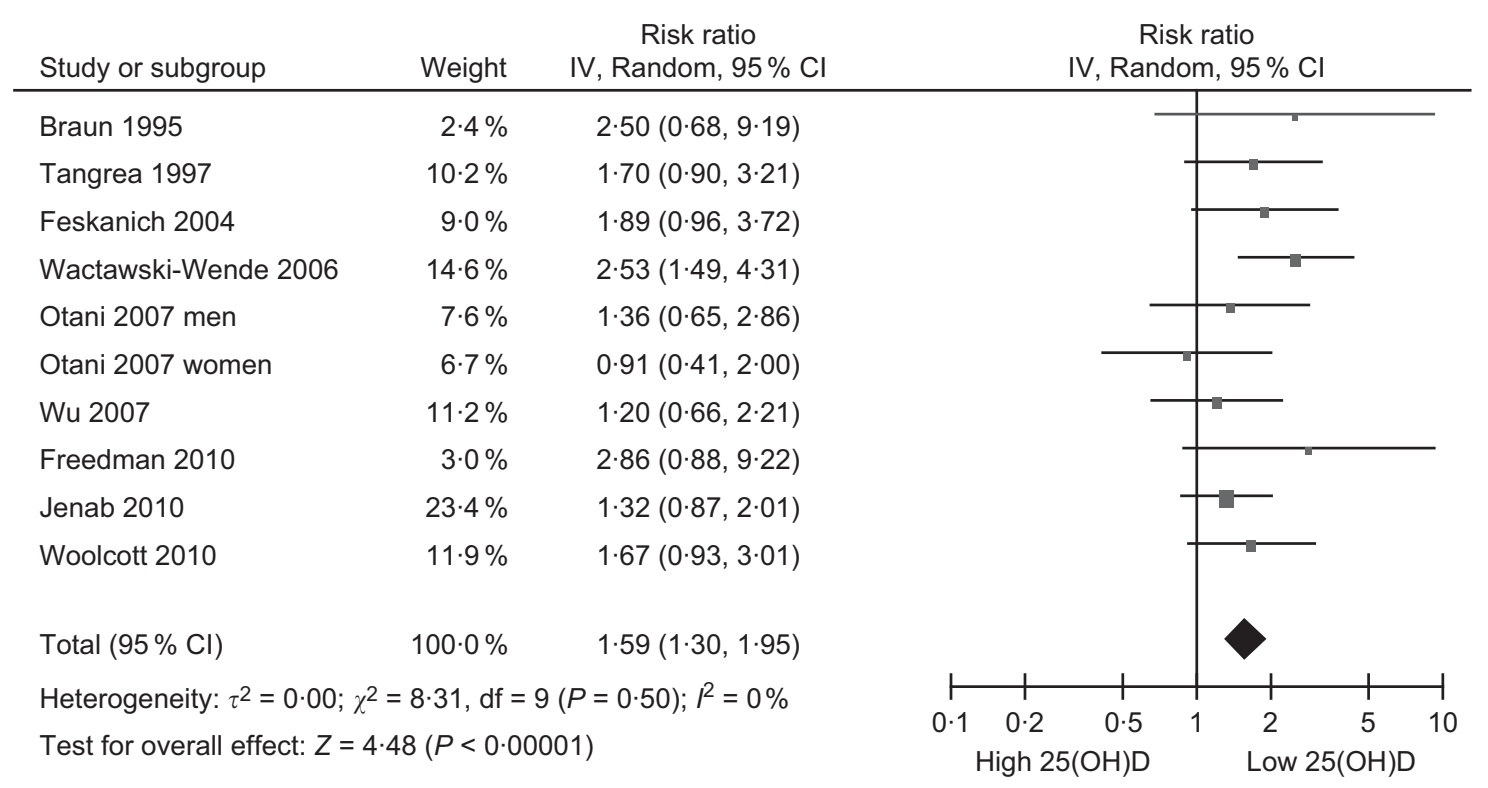

Fig. 3 Forest plot of relative risks of colorectal cancer associated with the lowest 25-hydroxyvitamin D (25(OH)D) category compared with the highest (or reference) in cohort studies (the study by Garland et al. ${ }^{(62)}$ is excluded because it did not report $95 \% \mathrm{Cl}$ )

that vitamin D may protect against CVD was a populationbased case-control study from New Zealand, published in 1990, which found a significant inverse association between $25(\mathrm{OH}) \mathrm{D}$ levels and risk of myocardial infarction ${ }^{(93)}$. However, because of the case-control design with collection of blood samples after the onset of disease, uncertainty remained as to whether or not $25(\mathrm{OH}) \mathrm{D}$ levels in cases had been affected by the disease process.

The first cohort study comparing baseline $25(\mathrm{OH}) \mathrm{D}$ levels and risk of subsequent CVD was not published until 2005. That study of elderly people in Finland showed a significant inverse association between baseline $25(\mathrm{OH}) \mathrm{D}$ levels and subsequent risk of acute myocardial infarction, but not of stroke (Table 3$)^{(94)}$. The study was initially unnoticed, possibly because vitamin $\mathrm{D}$ was one of many nutrients examined. The publication that drew the notice of researchers was from the Framingham Offspring Study which found that participants with $25(\mathrm{OH}) \mathrm{D}$ levels $<10 \mu \mathrm{g} / \mathrm{ml}(25 \mathrm{nmol} / \mathrm{l})$ had nearly double the risk of CVD during follow-up compared with those $\geq 15 \mu \mathrm{g} / \mathrm{ml}(37 \cdot 5 \mathrm{nmol} / \mathrm{l})^{(95)}$. Since then, there has been a rush of publications from cohort studies of communitybased samples, with eleven other studies reporting on the association between $25(\mathrm{OH}) \mathrm{D}$ levels and risk of CVD (Table 3) ${ }^{(96-106)}$. Although not all of these studies have reported significant inverse associations, when combined, overall they show that participants in the lowest $25(\mathrm{OH}) \mathrm{D}$ category have a $35 \%$ increased risk of CVD compared with the reference category, after adjusting for covariates including (in most studies) obesity and physical activity (Fig. 4). Still, this small increase in risk indicates that the association is a weak one, and residual confounding remains a possible explanation for it.
Only one RCT with sufficient power to detect any beneficial effect on CVD incidence has been carried out. This is the Women's Health Initiative RCT, which randomised over 36000 women aged 50-79 years to taking daily doses of vitamin $\mathrm{D}(10 \mu \mathrm{g})$ and $\mathrm{Ca}(1000 \mathrm{mg})$ or placebo (as reported above for colorectal cancer). There was no difference between treatment and placebo groups in the risk of CVD during the 7-year follow-up period ${ }^{(107)}$. The lack of a treatment effect is attributed to the limitations of this trial ${ }^{(108)}$, as outlined above for colorectal cancer.

Research has also examined the association that vitamin D status has with cardiovascular risk factors, particularly blood pressure and type 2 diabetes. For blood pressure, there have been numerous cross-sectional studies and at least four cohort studies which have compared baseline 25(OH)D levels with subsequent risk of hypertension ${ }^{(109,110)}$, with a $27 \%$ reduction in risk of hypertension for participants in the highest vitamin D category compared with the lowest ${ }^{(110)}$. However, RCT of vitamin D supplementation and blood pressure have produced conflicting results, with most longterm studies showing no beneficial effect ${ }^{(109)}$. It is possible that vitamin D may affect arterial function through different mechanisms than blood pressure, since intimal medial thickening of carotid arteries is inversely associated with $25(\mathrm{OH}) \mathrm{D}^{(111)}$, although vitamin D supplementation has been found to have inconsistent effects on endothelial function $^{(112,113)}$.

With regard to type 2 diabetes, there have also been numerous cross-sectional studies showing inverse associations between blood 25(OH)D levels and risk of diabetes $^{(114)}$, and at least five cohort studies showing that baseline $25(\mathrm{OH}) \mathrm{D}$ levels predict diabetes or other 
Table 3 Relative risk of CVD and all-cause mortality associated with low baseline level of 25-hydroxyvitamin D (25(OH)D) in cohort studies

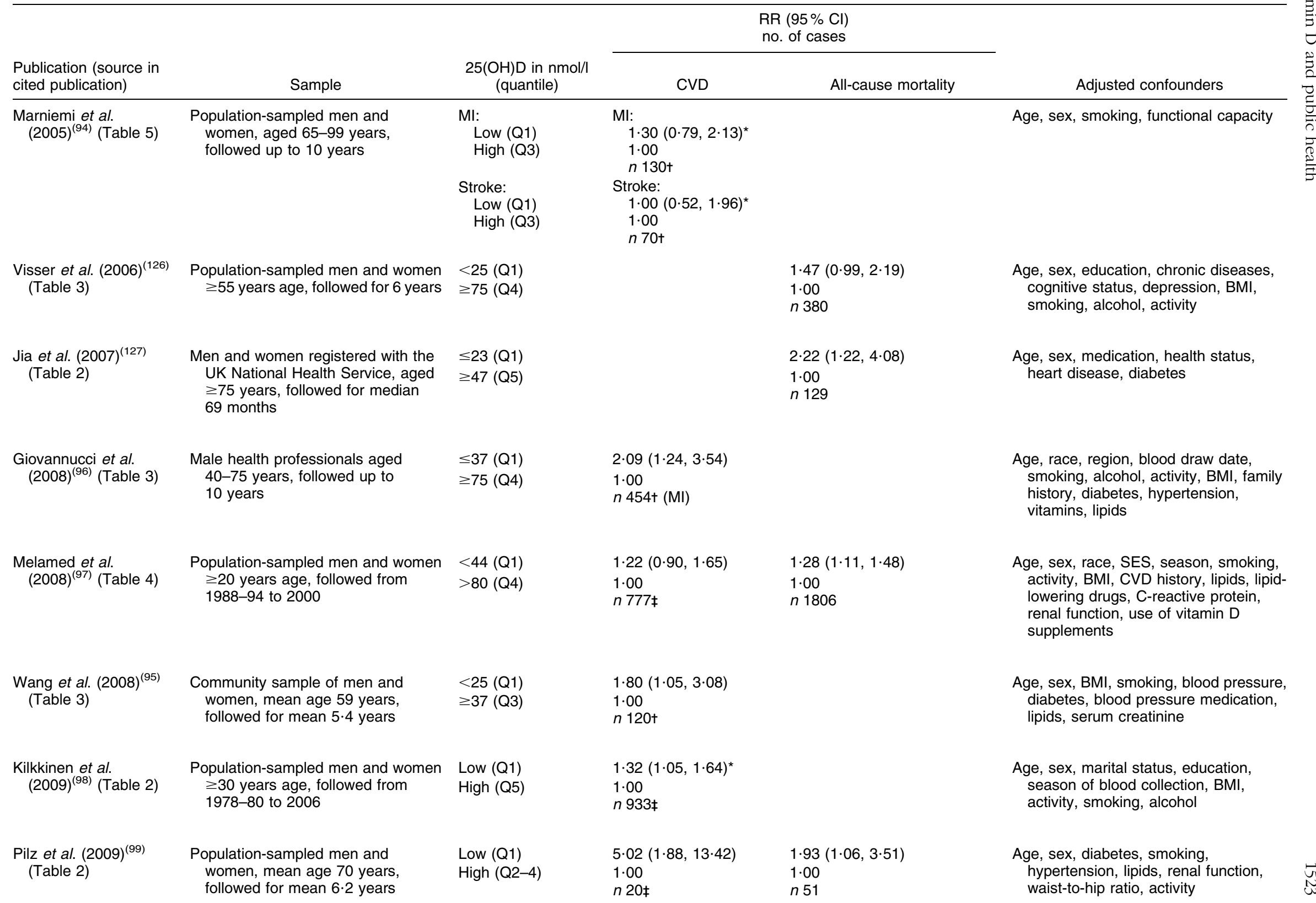




\begin{tabular}{|c|c|c|c|c|c|}
\hline \multirow{2}{*}{$\begin{array}{l}\text { Publication (source in } \\
\text { cited publication) }\end{array}$} & \multirow[b]{2}{*}{ Sample } & \multirow{2}{*}{$\begin{array}{l}\text { 25(OH)D in nmol/l } \\
\text { (quantile) }\end{array}$} & \multicolumn{2}{|c|}{$\begin{array}{l}\mathrm{RR}(95 \% \mathrm{Cl}) \\
\text { no. of cases }\end{array}$} & \multirow[b]{2}{*}{ Adjusted confounders } \\
\hline & & & CVD & All-cause mortality & \\
\hline \multirow{2}{*}{$\begin{array}{l}\text { Semba et al. }(2009)^{(128)} \\
\quad \text { (Table 2) }\end{array}$} & \multirow{2}{*}{$\begin{array}{l}\text { Community-dwelling women aged } \\
70-79 \text { years, followed for median } \\
6 \text { years }\end{array}$} & <38 (Q1) & & $2 \cdot 45(1 \cdot 12,5 \cdot 36)$ & \multirow{2}{*}{$\begin{array}{l}\text { Age, race, education, season, BMI, } \\
\text { smoking, supplement use, physical } \\
\text { activity, lipids, history of CVD and renal } \\
\text { disease }\end{array}$} \\
\hline & & $>67(\mathrm{Q} 4)$ & & $\begin{array}{l}1 \cdot 00 \\
n 100\end{array}$ & \\
\hline \multirow{2}{*}{$\begin{array}{l}\text { Szulc et al. }(2009)^{(129)} \\
\quad(\text { Table 4) }\end{array}$} & \multirow{2}{*}{$\begin{array}{l}\text { Men recruited from insurance rolls, } \\
\text { aged } \geq 50 \text { years, followed for } \\
3 \text { to } 10 \text { years }\end{array}$} & Low (Q1) & & $1.70(0.95,3.05)$ & \multirow{2}{*}{$\begin{array}{l}\text { Age, BMI, smoking, physical } \\
\text { performance, physical activity, heart } \\
\text { disease, diabetes, Parkinson's } \\
\text { disease, vitamin D supplementation }\end{array}$} \\
\hline & & High (Q4) & & $\begin{array}{l}1 \cdot 00 \\
n 182\end{array}$ & \\
\hline \multirow{2}{*}{$\begin{array}{l}\text { Anderson et al. } \\
\qquad(2010)^{(100)}(\text { Table 6) }\end{array}$} & \multirow{2}{*}{$\begin{array}{l}\text { Men and women in a community } \\
\text { health-care plan with a vitamin D } \\
\text { blood test during } 2000-09 \text {, mean } \\
\text { age } 55 \text { years, followed for mean of } \\
1 \cdot 3 \text { years }\end{array}$} & $\leq 37(\mathrm{Q} 1)$ & $1 \cdot 45(1 \cdot 18,1 \cdot 67) \S$ & $1 \cdot 77(1 \cdot 49,2 \cdot 10) \S$ & \multirow{2}{*}{$\begin{array}{l}\text { Age, sex, hypertension, lipids, diabetes, } \\
\text { peripheral vascular disease }\end{array}$} \\
\hline & & >75 (Q3) & $\begin{array}{l}1 \cdot 00 \\
n 763 \|(\mathrm{MI})\end{array}$ & $\begin{array}{l}1 \cdot 00 \\
n 1193\end{array}$ & \\
\hline $\begin{array}{l}\text { Bolland et al. }(2010)^{(101)} \\
\quad(\text { Table 2) }\end{array}$ & $\begin{array}{l}\text { Women volunteers in a clinical trial, } \\
\text { aged }>55 \text { years, followed for } \\
5 \text { years }\end{array}$ & $\begin{array}{l}<50(\mathrm{Q} 1) \\
\geq 50(\mathrm{Q} 2)\end{array}$ & $\begin{array}{l}1 \cdot 2(0 \cdot 8,1 \cdot 8) \\
1 \cdot 0 \\
n 110+\end{array}$ & $\begin{array}{l}0 \cdot 9(0 \cdot 5,1 \cdot 6) \\
1 \cdot 0 \\
n 63\end{array}$ & $\begin{array}{l}\text { Treatment allocation, age, weight, } \\
\text { smoking, blood pressure, CVD history, } \\
\text { lipids, diabetes }\end{array}$ \\
\hline $\begin{array}{l}\text { Cawthon et al. } \\
\qquad(2010)^{(102)}(\text { Table 3) }\end{array}$ & $\begin{array}{l}\text { Community sample of men, aged } \\
\geq 65 \text { years, followed for mean } \\
7 \cdot 3 \text { years }\end{array}$ & $\begin{array}{l}<50(\mathrm{Q} 1) \\
\geq 75(\mathrm{Q} 4)\end{array}$ & $\begin{array}{l}1 \cdot 52(0 \cdot 83,2 \cdot 80) \\
1 \cdot 00 \\
n 110 \ddagger\end{array}$ & $\begin{array}{l}0.95(0 \cdot 68,1 \cdot 34) \\
1 \cdot 00 \\
n 330\end{array}$ & $\begin{array}{l}\text { Age, race, education, clinic, season of } \\
\text { blood draw, body fat, weight, health } \\
\text { status, activity, medical history, serum } \\
\text { Ca \& P, renal function }\end{array}$ \\
\hline \multirow[t]{2}{*}{$\begin{array}{l}\text { Hutchinson et al. } \\
\qquad(2010)^{(103)} \text { (Tables } 2 \\
\text { \& 3) }\end{array}$} & \multirow[t]{2}{*}{$\begin{array}{l}\text { Population-sampled men and } \\
\text { women, mean age } 59 \text { years, } \\
\text { followed for mean } 11.7 \text { years }\end{array}$} & $\begin{array}{l}\text { Non-smokers: } \\
\text { Low (Q1) } \\
\text { High (Q4) }\end{array}$ & $\begin{array}{l}\text { Non-smokers: } \\
1 \cdot 08(0 \cdot 79,1 \cdot 48) \\
1 \cdot 00 \\
n 325 \ddagger\end{array}$ & $\begin{array}{l}\text { Non-smokers: } \\
\begin{array}{l}1 \cdot 32(1 \cdot 07,1 \cdot 62) \\
1 \cdot 00 \\
n 798\end{array}\end{array}$ & \multirow[t]{2}{*}{$\begin{array}{l}\text { Age, sex, BMI, activity, diabetes, } \\
\text { hypertension, creatinine, history of } \\
\text { CVD and cancer }\end{array}$} \\
\hline & & $\begin{array}{l}\text { Smokers: } \\
\text { Low (Q1) } \\
\text { High (Q4) }\end{array}$ & $\begin{array}{l}\text { Smokers: } \\
0.93(0 \cdot 61,1 \cdot 44) \\
1 \cdot 00 \\
n 188 \ddagger\end{array}$ & $\begin{array}{l}\text { Smokers: } \\
1 \cdot 06(0 \cdot 83,1 \cdot 35) \\
1 \cdot 00 \\
n 561\end{array}$ & \\
\hline $\begin{array}{l}\text { Jassal et al. }(2010)^{(104)} \\
\quad \text { (Table 2) }\end{array}$ & $\begin{array}{l}\text { Community sample of men and } \\
\text { women, mean age } 74 \text { years, } \\
\text { followed for mean } 6 \cdot 4 \text { years }\end{array}$ & Per SD increase & $\begin{array}{l}1 \cdot 07(0 \cdot 86,1 \cdot 33) \\
n 111 \ddagger\end{array}$ & & $\begin{array}{l}\text { Age, sex, BMI, season of blood draw, } \\
\text { blood pressure, lipids, glucose, } \\
\text { exercise, CVD, renal function, } \\
\text { medication }\end{array}$ \\
\hline
\end{tabular}


glycaemic measures ${ }^{(115-119)}$. Another cohort study has reported that people with increased sun exposure have a reduced risk of diabetes ${ }^{(120)}$. However, the few RCT to date have shown inconsistent results ${ }^{(121-123)}$.

In summary, vitamin $\mathrm{D}$ research over the last 10 years has increased more rapidly for CVD than any other disease group (Fig. 1). A substantial number of communitysampled cohort studies have been carried out which collectively show that low baseline blood 25(OH)D levels predict increased risk of CVD (Fig. 4). Substantial clinical and laboratory research has identified a range of mechanisms by which vitamin D may affect risk of CVD, including alterations in immune function, cardiac size and function, insulin resistance and arterial function ${ }^{(124)}$. However, the association between vitamin D and CVD is weak and, as for colorectal cancer, large RCT are required to confirm the findings from the observational studies.

\section{All-cause mortality}

The accumulating research on vitamin D and CVD inevitably led to an interest in the possible association between vitamin $\mathrm{D}$ and all-cause mortality, given that CVD is the leading cause of mortality in developed countries. Research on this topic has been stimulated greatly by a recent meta-analysis of RCT originally undertaken to determine the effect of vitamin D supplementation on risk of fractures (summarised above). This meta-analysis found that participants in these trials given vitamin $\mathrm{D}$ had a $7 \%$ decrease in all-cause mortality compared with those receiving placebos ${ }^{(125)}$. The weighted dose of vitamin D in these trials was only $528 \mathrm{IU} / \mathrm{d}$, suggesting that vitamin D may decrease mortality by much greater amounts if given in higher doses. This analysis has stimulated other researchers of cohort studies to include allcause mortality as an outcome, along with CVD (Table 3). Surprisingly, the first cohort study to report on the association between baseline 25(OH)D levels and subsequent risk of death, which was from the Netherlands, was missed in the subsequent rush of papers on this topic, perhaps because its focus was on predicting admission to nursing homes rather than death ${ }^{(126)}$. However, since then, eleven other cohort studies have reported on this association

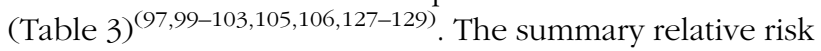
from these studies is 1.42 , when comparing the lowest $25(\mathrm{OH}) \mathrm{D}$ category with the reference (Fig. 5), which indicates a weak association across the range of $25(\mathrm{OH}) \mathrm{D}$ concentrations in the general population. Although a small effect, a reduction of this amount in all-cause mortality would be substantial, so it is potentially of great health significance. However, large RCT are required to confirm if vitamin $\mathrm{D}$ supplementation by itself reduces all-cause mortality since another meta-analysis has concluded that vitamin D is beneficial only when combined with $\mathrm{Ca}^{(23)}$.

\section{Infection and immune function}

The final disease group considered in the present overview is infection and the effects of vitamin $\mathrm{D}$ on immune 


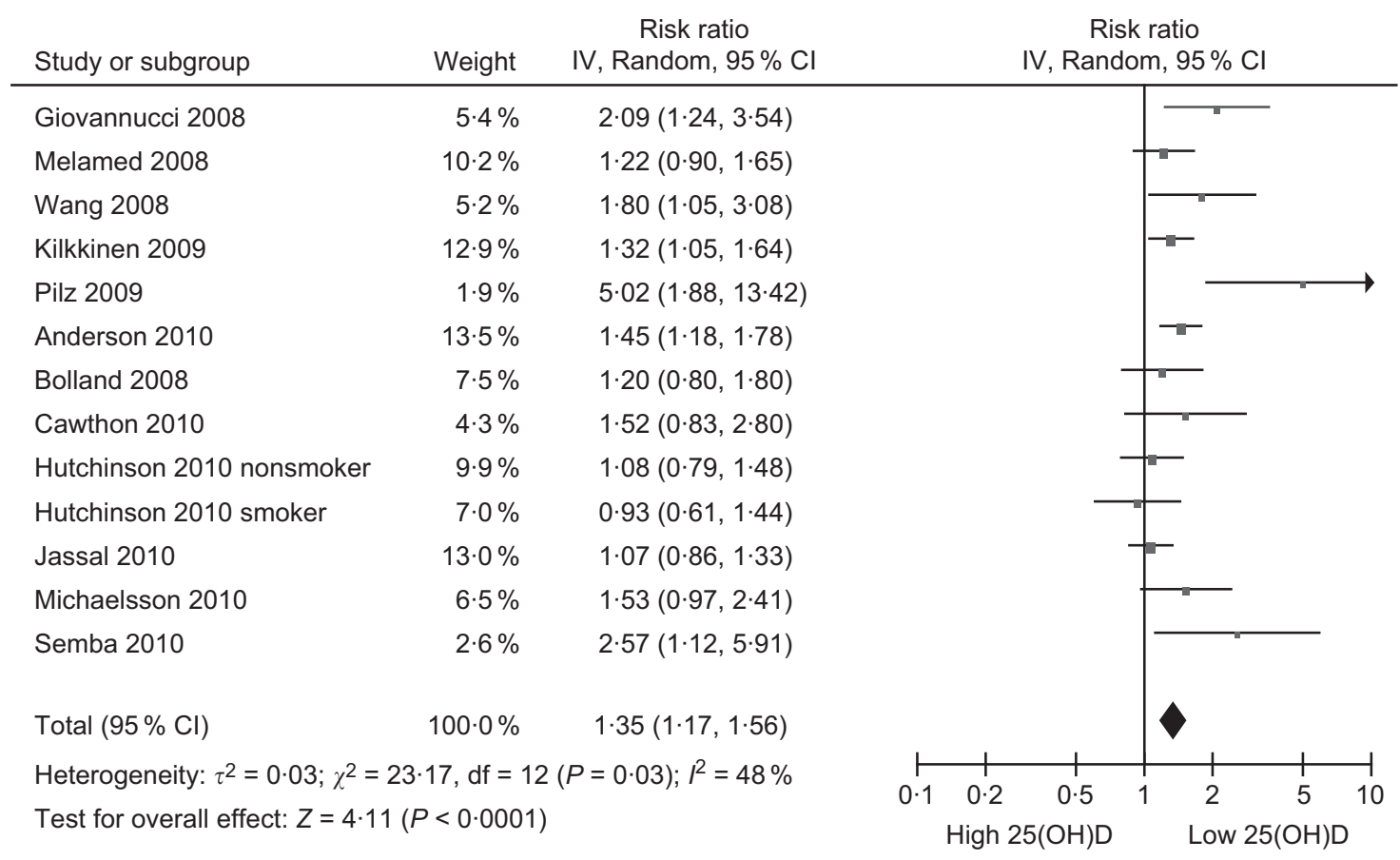

Fig. 4 Forest plot of relative risks of CVD associated with the lowest 25-hydroxyvitamin $\mathrm{D}(25(\mathrm{OH}) \mathrm{D})$ category compared with the highest (or reference) in cohort studies (the study by Marniemi et al. ${ }^{(94)}$ is excluded because it reported relative risks separately for myocardial infarction and stroke)

function. Research on the beneficial effects of vitamin D against infection extends back to the beginning of the 20th century when Nils Finsen, a physician from Copenhagen, was awarded the Nobel Prize for the heliotherapy he developed using the eponymous lamp to cure lupus vulgaris, a disfiguring skin disease caused by tuberculosis (TB) which typically affects the face ${ }^{(130)}$. The success of his treatment eventually led to the establishment of sanatoria for TB patients where a key part of the treatment was exposure to sunlight ${ }^{(131)}$. Up until the early 1950s, patients with TB were being increasingly treated with vitamin $\mathrm{D}^{(132)}$. However, the introduction of antibiotics in the 1950s, with their greater effectiveness, soon resulted in the abandonment of vitamin $\mathrm{D}$ as a therapeutic agent against TB.

Immune function can be split broadly into two components: innate and acquired. The key agents of the innate immune system are antimicrobial peptides, which are the immediate, non-specific, first line of defence for plants and animals against infectious organisms ${ }^{(133)}$. The main antimicrobial peptide in man is cathelicidin. An influential paper published in 2006 showed that vitamin D increases synthesis of cathelicidin ${ }^{(134)}$, and it is through this mechanism that vitamin $\mathrm{D}$ is thought to protect against $\mathrm{TB}$ and other infectious diseases ${ }^{(135,136)}$. Low plasma levels of cathelicidin have recently been shown to predict increased mortality from infectious disease in renal dialysis patients ${ }^{(137)}$. A meta-analysis has shown that TB cases have lower $25(\mathrm{OH}) \mathrm{D}$ levels than controls ${ }^{(138)}$, and vitamin D has been used in recent RCT with mixed results ${ }^{(139,140)}$. There is also increasing evidence of a link between vitamin D status and viral respiratory tract infections. Observational studies mostly show lower $25(\mathrm{OH}) \mathrm{D}$ levels in cases compared with controls, and four out of five RCT have shown that vitamin D supplementation reduces incidence of respiratory tract infection or influenza ${ }^{(141)}$.

Vitamin D also affects acquired immune function and risk of related autoimmune diseases, such as multiple sclerosis and type 1 diabetes. The occurrence of multiple sclerosis increases with latitude ${ }^{(142)}$ and evidence from observational studies shows that decreased sun exposure and 25(OH)D levels are risk factors for this disease ${ }^{(143-145)}$. For type 1 diabetes, animal studies over 30 years ago identified a pancreatic receptor to vitamin $\mathrm{D}^{(146)}$ and showed that vitamin $\mathrm{D}$ deficiency decreased insulin secretion by the pancreas ${ }^{(147)}$. A meta-analysis of observational studies in man has confirmed these findings, with a history of taking vitamin D supplements during childhood being associated with a $29 \%$ decreased risk of type 1 diabetes compared with children who did not take vitamin $\mathrm{D}^{(148)}$.

In summary, research on vitamin $\mathrm{D}$ and immune function is increasing (Fig. 1). The evidence indicates that vitamin $\mathrm{D}$ may protect against a wide range of infections including $\mathrm{TB}$ and respiratory infections. RCT that are currently underway should provide a clear picture within the next $5-10$ years as to whether vitamin D is effective against these diseases. 


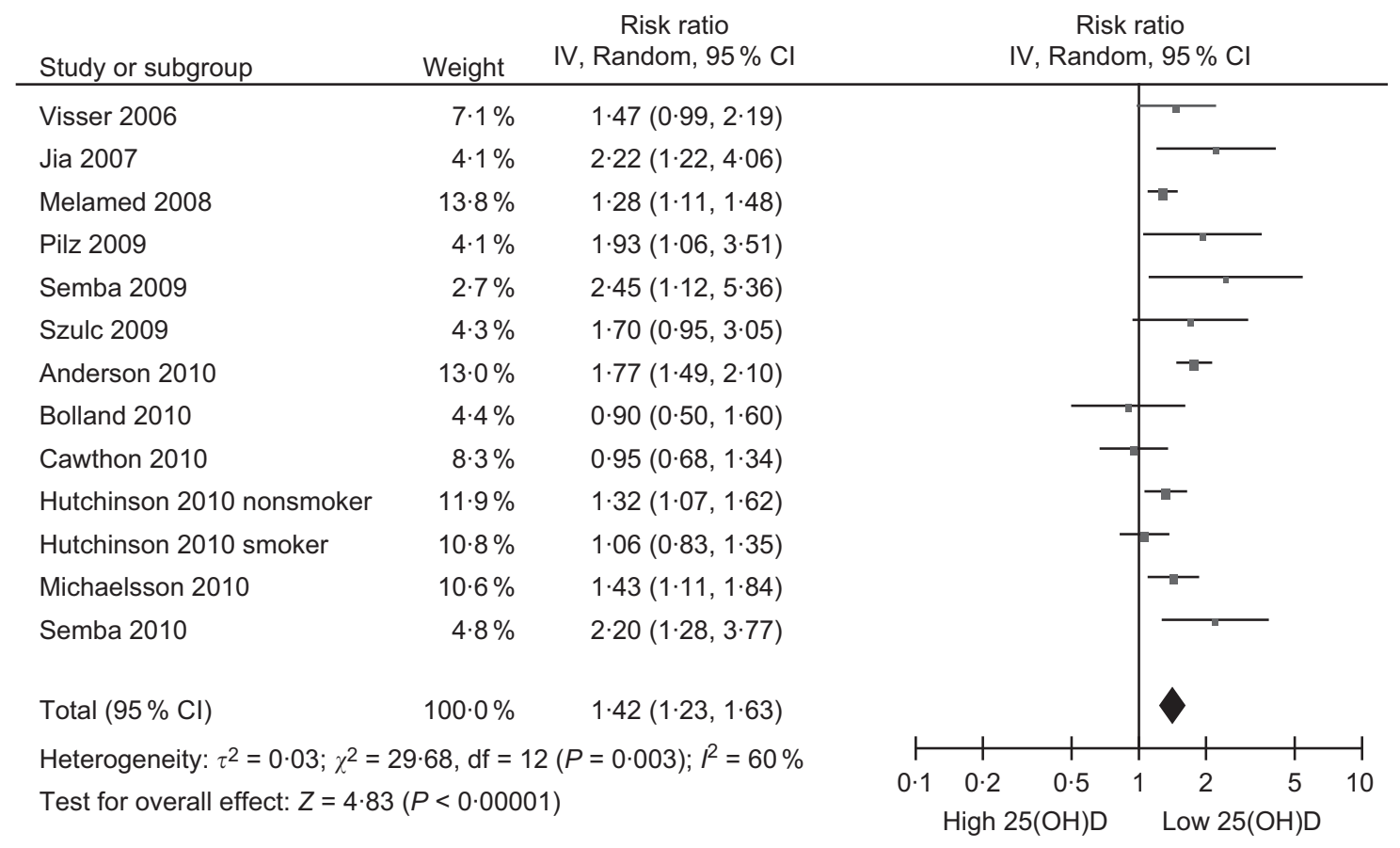

Fig. 5 Forest plot of relative risks of all-cause mortality associated with the lowest 25-hydroxyvitamin $\mathrm{D}(25(\mathrm{OH}) \mathrm{D}) \mathrm{category}$ compared with the highest (or reference) in cohort studies

\section{Institute of Medicine report}

The IOM in the USA released its report on the recommended dietary intakes of $\mathrm{Ca}$ and vitamin $\mathrm{D}$ at the end of November $2010^{(4)}$. It is a substantial document, based largely on two commissioned systematic reviews. The first review, by researchers in Ottawa, summarised the literature on vitamin $\mathrm{D}$ and bone health published up to mid-2006, with a focus on $\mathrm{RCT}^{(149)}$. The second review, by researchers in Boston, was of publications up to April $2009^{(150)}$. It updated the bone data published since the Ottawa review, but also reviewed many other health outcomes. It focused on RCT and cohort studies, and excluded cross-sectional and case-control studies. The IOM report mainly relied on these two reviews, but also considered data from other study designs including observational studies (e.g. case-control and cross-sectional) in man and animal studies of biological mechanisms. It assessed the evidence on vitamin $\mathrm{D}$ for a wide range of outcomes (Table 4.1 of the IOM report), which surprisingly did not include all-cause mortality. Its main conclusions with regard to vitamin D were that: (i) vitamin D status was related only to bone health; and (ii) $25(\mathrm{OH}) \mathrm{D}$ levels of $50 \mathrm{nmol} / 1$ represent vitamin $\mathrm{D}$ sufficiency because above this level there was no consistent evidence of increased health benefit. On this basis, the IOM decided to marginally increase the dietary reference intake (from the previous recommendations in their 1997 report) to $15 \mu \mathrm{g} / \mathrm{d}$ for adults up to 70 years of age and $20 \mu \mathrm{g} / \mathrm{d}$ above this age. The smallness of this increase has surprised many vitamin D researchers and clinicians, since these daily intakes will increase $25(\mathrm{OH}) \mathrm{D}$ levels by only $5-20 \mathrm{nmol} / \mathrm{l}$ depending on a person's starting 25(OH)D level ${ }^{(8)}$.

As with any report of this magnitude, the evidence on which its conclusions are based will rapidly become out of date; this is already happening with the IOM report. For example, seven of the nine cohort studies of fractures in Table 1, all published from $2007^{(39-45)}$, are not mentioned in the IOM report or the systematic reviews on which it is based; while for colorectal cancer, two out of the ten cohort studies in Table 2 were not included ${ }^{(61,70)}$, one of which ${ }^{(151)}$ was an update of the third NHANES included in the report.

However, it is in the areas of CVD and all-cause mortality, where publications are more recent, that the omissions are greatest. In the section on CVD, there is no mention in the IOM report about nine of the cohort studies of CVD in Table $3^{(98-106)}$, all published from 2009, although the study by Bolland et $a l^{(101)}$ is described elsewhere in the report. Instead, the IOM report focuses on the papers from the Framingham Offspring Study, which it describes as having a U-shaped association between CVD risk and 25(OH)D above $75 \mathrm{nmol} / \mathrm{l}^{(95)}$, and the initial mortality report from NHANES which it also described as having a U-shaped dose-response relationship ${ }^{(97)}$; but made no mention in the discussion of chapter 4 on health outcomes of a further analysis of the NHANES data of people aged $\geq 65$ years which found an inverse linear association across the population distribution of 
$25(\mathrm{OH}) \mathrm{D}$ rather than a U-shaped relationship ${ }^{(152)}$. The possible U-shaped dose-response relationship is one of the rationales used by the IOM for keeping the cut-off point for vitamin D sufficiency at a $25(\mathrm{OH}) \mathrm{D}$ concentration of $50 \mathrm{nmol} / \mathrm{l}$. Of the cohort studies on CVD not cited in the IOM report which had more than two $25(\mathrm{OH}) \mathrm{D}$ comparison groups, two described a U-shaped association in all $^{(105)}$ or some (i.e. non-smokers) ${ }^{(103)}$ of their participants and four showed evidence of an inverse linear association $^{(98,100,102,106)}$. If the latter are combined with the other publication mentioned by the IOM from the study of US male health professionals which showed a significant dose-response association ${ }^{(96)}$, then the emphasis by the IOM about a likely U-shaped dose-response relationship between $25(\mathrm{OH}) \mathrm{D}$ and $\mathrm{CVD}$, and their conclusion that the $25(\mathrm{OH}) \mathrm{D}$ evidence does not show a relationship with risk for developing CVD, do not look convincing.

Death trumps all other outcomes, so even more surprising is the absence of all-cause mortality from the list of health outcomes in Table $4 \cdot 1$ of the IOM report, even though this outcome was examined in one of the systematic reviews used by the report ${ }^{(150)}$. The meta-analysis of RCT of vitamin D supplementation (with or without $\mathrm{Ca}$ ) is not even listed in the references of the IOM report, despite being published in $2007^{(125)}$. Seven of the twelve cohort studies in Table 3 which have published data on the association between $25(\mathrm{OH}) \mathrm{D}$ and all-cause mortality are not referenced in the IOM report ${ }^{(99,100,102,103,105,106,129)}$. This omission is all the more surprising when the IOM report includes many references from 2010, which suggests that there was selective reporting of publications from the two years (2009 and 2010) preceding the release of the report.

Despite the above limitations, the additional publications from cohort studies since 2009, which have added greatly to the body of evidence, have not diminished but increased the need for evidence from large RCT to determine with greater certainty whether vitamin D protects against the diseases covered in the present overview. By increasing the dietary reference intake only up to $20 \mu \mathrm{g} / \mathrm{d}$ (for the oldest age groups) the IOM has provided a window of opportunity for researchers to undertake RCT for disease outcomes. If the daily dietary reference intake had been increased up to $50 \mu \mathrm{g}$ or higher, it would have been ethically difficult for researchers to do RCT as they would have been obligated to give participants in the control arm this high dose. The resulting contamination in the control arm would have made it difficult to detect any beneficial effect from vitamin D. At least two large RCT using higher doses of vitamin D have started. These are: (i) the US VITAL study (www. vitalstudy.org), which is recruiting 20000 older adults to determine if $50 \mu \mathrm{g}$ vitamin $\mathrm{D}_{3} / \mathrm{d}$ prevents cancer and CVD (ClinicalTrials.gov identifier: NCT01169259); and (ii) the ViDA study from New Zealand, which is recruiting 5100 older adults to determine if $2.5 \mathrm{mg}$ vitamin $\mathrm{D}_{3} /$ month prevents CVD, respiratory disease (including infections) and non-vertebral fractures (www.ANZCTR.org.au registration number: ACTRN12611000402943).

\section{Public health implications}

Why do we need RCT to prove the benefit of vitamin D if the cohort data look so convincing? First, the recent evidence for other micronutrients, such as vitamins A, B, C and $\mathrm{E}$, has shown that results from observational studies, which generally reported inverse associations between nutrient status and risk of cancer and CVD disease, have not been confirmed by RCT; in fact, supplementation increases mortality ${ }^{(1,2)}$. Hence the need for caution with vitamin D and the need to show that it is both safe and effective; although vitamin D may be different from other micronutrients because it is a hormone ${ }^{(153)}$. Second, the ultimate goal of vitamin D research, if vitamin D is truly beneficial, must be for state-funded programmes to increase vitamin D levels in the general population through the available strategies, such as increased (but safe) sun exposure, fortification and supplementation. If the state is to invest in such programmes, there will be an opportunity cost (from less money to spend on other programmes) and it needs evidence from RCT and cost-effectiveness analyses to show that any benefit from investment in vitamin D programmes is equivalent to or higher than that for other publicly funded interventions. In the absence of state-funded programmes, health inequalities will increase if vitamin D is beneficial, since poorer sections of the community, which typically have the lowest vitamin D levels, are likely to have the least capacity to increase their vitamin D levels.

Assuming that RCT show benefit, the strategies used in future public health programmes will be influenced by some of the disputed evidence described above. For example, the uncertainty about whether vitamin D is associated linearly or in a U-shaped pattern with disease risk will determine whether population or high-risk approaches to prevention are used ${ }^{(154)}$. If the association between vitamin D status and risk of disease were inversely linear, then programmes targeting the general population would be required. However, if the association is U-shaped, then high-risk strategies which identify and target people with low vitamin D levels would be preferred, since people with high levels would not gain from having even higher vitamin D levels.

Another point of contention, which will shape the type of interventions, is whether vitamin $\mathrm{D}$ is beneficial by itself, or whether it needs to be combined with $\mathrm{Ca}$. Ca is a much more expensive supplement than vitamin D to use in public health campaigns since it needs to be taken on a daily basis because of its water solubility. As well, there are safety issues with $\mathrm{Ca}^{(155)}$ that were downplayed in the IOM report. In contrast, vitamin D is fat soluble and can be taken less often (e.g. monthly) ${ }^{(156)}$. This greatly decreases the cost, and respondent burden, for running population-wide supplementation programmes. 


\section{Conclusions}

Cohort studies show that baseline $25(\mathrm{OH}) \mathrm{D}$ levels predict increased risk of fractures, colorectal cancer, CVD and allcause mortality. However, these associations are weak, with relative risks comparing the lowest $25(\mathrm{OH}) \mathrm{D}$ category with the highest (or reference) being in the range of $1 \cdot 3$ to $1 \cdot 6$. While these could be underestimates of the true effect (for reasons discussed in the Methods), it is also possible they are caused by confounding from other variables such as obesity and physical activity. RCT using vitamin $\mathrm{D}$ doses $\geq 50 \mu \mathrm{g} / \mathrm{d}$ are required to determine whether vitamin $\mathrm{D}$ protects against these diseases. The evidence in the IOM report is now out of date for the above outcomes. However, its recommendation for daily vitamin D intakes up to $20 \mu \mathrm{g}$ provides a window for researchers to undertake higher-dose RCT. These are now starting and should provide definitive answers about the health benefits of vitamin D during the coming decade.

\section{Acknowledgements}

Funding was provided by the Health Research Council of New Zealand and the Accident Compensation Commission. No conflicts of interest declared.

\section{References}

1. Byers T (2010) Anticancer vitamins $d u$ jour - the ABCED's so far. Am J Epidemiol 172, 1-3.

2. Bjelakovic G, Nikolova D, Gluud LL et al. (2008) Antioxidant supplements for prevention of mortality in healthy participants and patients with various diseases. Cochrane Database Syst Rev issue 2, CD007176.

3. Norman AW \& Bouillon R (2010) Vitamin D nutritional policy needs a vision for the future. Exp Biol Med (Maywood) 235, 1034-1045.

4. Institute of Medicine (2011) Dietary Reference Intakes for Calcium and Vitamin D. Washington, DC: National Academies Press.

5. Heaney RP \& Holick MF (2011) Why the IOM recommendations for vitamin D are deficient. J Bone Miner Res 26, 455-457.

6. Reid IR \& Avenell A (2011) Evidence-based policy on dietary calcium and vitamin D. J Bone Miner Res 26, 452-454.

7. Holick MF (2006) High prevalence of vitamin D inadequacy and implications for health. Mayo Clin Proc 81, 353-373.

8. Garland CF, French CB, Baggerly LL et al. (2011) Vitamin D supplement doses and serum 25-hydroxyvitamin D in the range associated with cancer prevention. Anticancer Res 31, 607-611.

9. Schwartz GG, Whitlatch LW, Chen TC et al. (1998) Human prostate cells synthesize 1,25-dihydroxyvitamin $\mathrm{D}_{3}$ from 25-hydroxyvitamin $\mathrm{D}_{3}$. Cancer Epidemiol Biomarkers Prev 7, 391-395.

10. Peterlik M \& Cross HS (2005) Vitamin D and calcium deficits predispose for multiple chronic diseases. Eur J Clin Invest 35, 290-304.

11. Haddad JG Jr \& Hahn TJ (1973) Natural and synthetic sources of circulating 25-hydroxyvitamin D in man. Nature 244, 515-517.
12. Poskitt EM, Cole TJ \& Lawson DE (1979) Diet, sunlight, and 25-hydroxy vitamin $\mathrm{D}$ in healthy children and adults. Br Med J 1, 221-223.

13. The Cochrane Collaboration (2011) Review Manager (RevMan) Version 5.1. Copenhagen: The Nordic Cochrane Centre.

14. Pittas AG, Chung M, Trikalinos T et al. (2010) Systematic review: vitamin D and cardiometabolic outcomes. Ann Intern Med 152, 307-314.

15. Grandi NC, Breitling LP \& Brenner H (2010) Vitamin D and cardiovascular disease: systematic review and meta-analysis of prospective studies. Prev Med 51, 228-233.

16. Bischoff-Ferrari HA, Giovannucci E, Willett WC et al. (2006) Estimation of optimal serum concentrations of 25-hydroxyvitamin $\mathrm{D}$ for multiple health outcomes. Am J Clin Nutr 84, 18-28.

17. Chick H (1975) The discovery of vitamins. Prog Food Nutr Sci 1, 1-20.

18. Aaron JE, Gallagher JC, Anderson J et al. (1974) Frequency of osteomalacia and osteoporosis in fractures of the proximal femur. Lancet 1, 229-233.

19. Aaron JE, Gallagher JC \& Nordin BE (1974) Seasonal variation of histological osteomalacia in femoral-neck fractures. Lancet 2, 84-85.

20. Weatherall M (2000) A meta-analysis of 25 hydroxyvitamin $\mathrm{D}$ in older people with fracture of the proximal femur. $N Z$ Med J 113, 137-140.

21. Richy F, Ethgen O, Bruyere O et al. (2004) Efficacy of alphacalcidol and calcitriol in primary and corticosteroidinduced osteoporosis: a meta-analysis of their effects on bone mineral density and fracture rate. Osteoporos Int $\mathbf{1 5}$, 301-310.

22. O'Donnell S, Moher D, Thomas K et al. (2008) Systematic review of the benefits and harms of calcitriol and alfacalcidol for fractures and falls. J Bone Miner Metab 26, 531-542.

23. Avenell A, Gillespie WJ, Gillespie LD et al. (2009) Vitamin $\mathrm{D}$ and vitamin $\mathrm{D}$ analogues for preventing fractures associated with involutional and post-menopausal osteoporosis. Cochrane Database Syst Rev issue 2, CD000227.

24. Chapuy MC, Arlot ME, Duboeuf F et al. (1992) Vitamin $D_{3}$ and calcium to prevent hip fractures in the elderly women. $N$ Engl J Med 327, 1637-1642.

25. Sanders KM, Stuart AL, Williamson EJ et al. (2010) Annual high-dose oral vitamin $\mathrm{D}$ and falls and fractures in older women: a randomized controlled trial. JAMA $\mathbf{3 0 3}$, $1815-1822$.

26. Salovaara K, Tuppurainen M, Karkkainen M et al. (2010) Effect of vitamin D(3) and calcium on fracture risk in 65- to 71-year-old women: a population-based 3-year randomized, controlled trial - the OSTPRE-FPS. J Bone Miner Res 25, 1487-1495.

27. Heaney RP (2008) Vitamin D in health and disease. Clin J Am Soc Nephrol 3, 1535-1541.

28. Vieth R, Bischoff-Ferrari H, Boucher BJ et al. (2007) The urgent need to recommend an intake of vitamin $\mathrm{D}$ that is effective. Am J Clin Nutr 85, 649-650.

29. Boonen S, Lips P, Bouillon R et al. (2007) Need for additional calcium to reduce the risk of hip fracture with vitamin D supplementation: evidence from a comparative metaanalysis of randomized controlled trials. J Clin Endocrinol Metab 92, 1415-1423.

30. DIPART (2010) Patient level pooled analysis of 68500 patients from seven major vitamin D fracture trials in US and Europe. BMJ 340, b5463.

31. Bischoff-Ferrari HA, Willett WC, Wong JB et al. (2005) Fracture prevention with vitamin D supplementation: a meta-analysis of randomized controlled trials. JAMA 293, 2257-2264.

32. Izaks GJ (2007) Fracture prevention with vitamin D supplementation: considering the inconsistent results. BMC Musculoskelet Disord 8, 26. 
33. Bischoff-Ferrari HA, Willett WC, Wong JB et al. (2009) Prevention of nonvertebral fractures with oral vitamin D and dose dependency: a meta-analysis of randomized controlled trials. Arch Intern Med 169, 551-561.

34. Sawka AM, Ismaila N, Cranney A et al. (2010) A scoping review of strategies for the prevention of hip fracture in elderly nursing home residents. PLoS One 5, e9515.

35. Bischoff-Ferrari HA, Dawson-Hughes B, Baron JA et al. (2007) Calcium intake and hip fracture risk in men and women: a meta-analysis of prospective cohort studies and randomized controlled trials. Am J Clin Nutr 86, 1780-1790.

36. Woo J, Lau E, Swaminathan R et al. (1990) Biochemical predictors for osteoporotic fractures in elderly Chinese - a longitudinal study. Gerontology 36, 55-58.

37. Cummings SR, Browner WS, Bauer D et al. (1998) Endogenous hormones and the risk of hip and vertebral fractures among older women. Study of Osteoporotic Fractures Research Group. N Engl J Med 339, 733-738.

38. Gerdhem P, Ringsberg KA, Obrant KJ et al. (2005) Association between 25-hydroxy vitamin D levels, physical activity, muscle strength and fractures in the prospective population-based OPRA Study of Elderly Women. Osteoporos Int 16, 1425-1431.

39. Garnero P, Munoz F, Sornay-Rendu E et al. (2007) Associations of vitamin $\mathrm{D}$ status with bone mineral density, bone turnover, bone loss and fracture risk in healthy postmenopausal women. The OFELY study. Bone 40, 716-722.

40. Roddam AW, Neale R, Appleby P et al. (2007) Association between plasma 25-hydroxyvitamin D levels and fracture risk: the EPIC-Oxford study. Am J Epidemiol 166, 1327-1336.

41. Cauley JA, Lacroix AZ, Wu L et al. (2008) Serum 25hydroxyvitamin $\mathrm{D}$ concentrations and risk for hip fractures. Ann Intern Med 149, 242-250.

42. Looker AC \& Mussolino ME (2008) Serum 25-hydroxyvitamin D and hip fracture risk in older US white adults. $J$ Bone Miner Res 23, 143-150.

43. van Schoor NM, Visser M, Pluijm SM et al. (2008) Vitamin D deficiency as a risk factor for osteoporotic fractures. Bone 42, 260-266.

44. Cauley JA, Parimi N, Ensrud KE et al. (2010) Serum 25hydroxyvitamin $\mathrm{D}$ and the risk of hip and nonspine fractures in older men. $J$ Bone Miner Res 25, 545-553.

45. Melhus H, Snellman G, Gedeborg R et al. (2010) Plasma 25hydroxyvitamin D levels and fracture risk in a communitybased cohort of elderly men in Sweden. J Clin Endocrinol Metab 95, 2637-2645.

46. Peller S \& Stephenson CS (1937) Skin irritation and cancer in the United States Navy. Am J Med Sci 194, 326-333.

47. Apperly FL (1941) The relation of solar radiation to cancer mortality in North America. Cancer Res 1, 191-195.

48. Garland CF \& Garland FC (1980) Do sunlight and vitamin D reduce the likelihood of colon cancer? Int J Epidemiol $\mathbf{9}$, 227-231.

49. Garland FC, Garland CF, Gorham ED et al. (1990) Geographic variation in breast cancer mortality in the United States: a hypothesis involving exposure to solar radiation. Prev Med 19, 614-622.

50. Schwartz GG \& Hulka BS (1990) Is vitamin D deficiency a risk factor for prostate cancer? (Hypothesis). Anticancer Res 10, 1307-1311.

51. Lefkowitz ES \& Garland CF (1994) Sunlight, vitamin D, and ovarian cancer mortality rates in US women. Int J Epidemiol 23, 1133-1136.

52. Newton R (1995) Non-Hodgkin's lymphoma and skin cancer. American data refute ultraviolet hypothesis. BMJ 311, 750-751.

53. International Agency for Research on Cancer (2008) Vitamin D and Cancer: A Report of the IARC Working Group on Vitamin D. Lyon: IARC.
54. Gandini S, Boniol M, Haukka J et al. (2011) Meta-analysis of observational studies of serum 25-hydroxyvitamin D levels and colorectal, breast and prostate cancer and colorectal adenoma. Int J Cancer 128, 1414-1424.

55. Moon SJ, Fryer AA \& Strange RC (2005) Ultraviolet radiation, vitamin $\mathrm{D}$ and risk of prostate cancer and other diseases. Photochem Photobiol 81, 1252-1260.

56. Yin L, Raum E, Haug U et al. (2009) Meta-analysis of longitudinal studies: serum vitamin $\mathrm{D}$ and prostate cancer risk. Cancer Epidemiol 33, 435-445.

57. Park SY, Cooney RV, Wilkens LR et al. (2010) Plasma 25hydroxyvitamin D and prostate cancer risk: the Multiethnic Cohort. Eur J Cancer 46, 932-936.

58. Yin L, Grandi N, Raum E et al. (2010) Meta-analysis: serum vitamin $\mathrm{D}$ and breast cancer risk. Eur $J$ Cancer 46, 2196-2205.

59. Engel P, Fagherazzi G, Boutten A et al. (2010) Serum $25(\mathrm{OH})$ vitamin $\mathrm{D}$ and risk of breast cancer: a nested case-control study from the French E3N cohort. Cancer Epidemiol Biomarkers Prev 19, 2341-2350.

60. Almquist M, Bondeson AG, Bondeson L et al. (2010) Serum levels of vitamin D, PTH and calcium and breast cancer risk - a prospective nested case-control study. Int J Cancer 127, 2159-2168.

61. Freedman DM, Looker AC, Abnet CC et al. (2010) Serum 25-hydroxyvitamin D and cancer mortality in the NHANES III study (1988-2006). Cancer Res 70, 8587-8597.

62. Garland CF, Comstock GW, Garland FC et al. (1989) Serum 25-hydroxyvitamin D and colon cancer: eight-year prospective study. Lancet 2, 1176-1178.

63. Braun MM, Helzlsouer KJ, Hollis BW et al. (1995) Colon cancer and serum vitamin D metabolite levels 10-17 years prior to diagnosis. Am J Epidemiol 142, 608-611.

64. Tangrea J, Helzlsouer K, Pietinen P et al. (1997) Serum levels of vitamin D metabolites and the subsequent risk of colon and rectal cancer in Finnish men. Cancer Causes Control 8, 615-625.

65. Feskanich D, Ma J, Fuchs CS et al. (2004) Plasma vitamin D metabolites and risk of colorectal cancer in women. Cancer Epidemiol Biomarkers Prev 13, 1502-1508.

66. Wactawski-Wende J, Kotchen JM, Anderson GL et al. (2006) Calcium plus vitamin D supplementation and the risk of colorectal cancer. $N$ Engl J Med 354, 684-696.

67. Otani T, Iwasaki M, Sasazuki S et al. (2007) Plasma vitamin $\mathrm{D}$ and risk of colorectal cancer: the Japan Public Health Center-Based Prospective Study. Br J Cancer 97, 446-451.

68. Wu K, Feskanich D, Fuchs CS et al. (2007) A nested case control study of plasma 25-hydroxyvitamin D concentrations and risk of colorectal cancer. J Natl Cancer Inst 99, $1120-1129$.

69. Jenab M, Bueno-de-Mesquita HB, Ferrari P et al. (2010) Association between pre-diagnostic circulating vitamin D concentration and risk of colorectal cancer in European populations: a nested case-control study. BMJ 340, b5500.

70. Woolcott CG, Wilkens LR, Nomura AM et al. (2010) Plasma 25-hydroxyvitamin D levels and the risk of colorectal cancer: the Multiethnic Cohort Study. Cancer Epidemiol Biomarkers Prev 19, 130-134.

71. Wolin KY, Yan Y, Colditz GA et al. (2009) Physical activity and colon cancer prevention: a meta-analysis. Br J Cancer 100, 611-616.

72. Scragg R \& Camargo CA Jr (2008) Frequency of leisure-time physical activity and serum 25-hydroxyvitamin D levels in the US population: results from the Third National Health and Nutrition Examination Survey. Am J Epidemiol 168, $577-586$.

73. Heaney RP, Davies KM, Chen TC et al. (2003) Human serum 25-hydroxycholecalciferol response to extended oral dosing with cholecalciferol. Am J Clin Nutr 77, 204-210. 
74. Newmark HL \& Heaney RP (2006) Calcium, vitamin D, and risk reduction of colorectal cancer. Nutr Cancer 56, 1-2.

75. Lappe JM, Travers-Gustafson D, Davies KM et al. (2007) Vitamin D and calcium supplementation reduces cancer risk: results of a randomized trial. Am J Clin Nutr 85, 1586-1591.

76. Helzlsouer KJ (2010) Overview of the Cohort Consortium Vitamin D Pooling Project of Rarer Cancers. Am J Epidemiol 172, 4-9.

77. Bao Y, Ng K, Wolpin BM et al. (2010) Predicted vitamin D status and pancreatic cancer risk in two prospective cohort studies. Br J Cancer 102, 1422-1427.

78. Gombart AF, Luong QT \& Koeffler HP (2006) Vitamin D compounds: activity against microbes and cancer. Anticancer Res 26, 2531-2542.

79. Scragg R (2011) Vitamin D: cardiovascular function and disease. In Vitamin D and Cancer, pp. 115-142. [DL Trump and CS Johnson, editors]. New York: Springer.

80. Taussig HB (1966) Possible injury to the cardiovascular system from vitamin D. Ann Intern Med 65, 1195-1200.

81. Seelig MS (1969) Vitamin D and cardiovascular, renal, and brain damage in infancy and childhood. Ann N Y Acad Sci $\mathbf{1 4 7}, 539-582$.

82. Taylor CB, Hass GM, Ho KJ et al. (1972) Risk factors in the pathogenesis of atherosclerotic heart disease and generalized atherosclerosis. Ann Clin Lab Sci 2, 239-243.

83. Yogamundi Moon J (1972) Factors affecting arterial calcification associated with atherosclerosis. A review. Atherosclerosis 16, 119-126.

84. Kummerow FA (1979) Nutrition imbalance and angiotoxins as dietary risk factors in coronary heart disease. Am J Clin Nutr 32, 58-83.

85. Hollis BW \& Horst RL (2007) The assessment of circulating $25(\mathrm{OH}) \mathrm{D}$ and $1,25(\mathrm{OH})_{2} \mathrm{D}$ : where we are and where we are going. J Steroid Biochem Mol Biol 103, 473-476.

86. Scragg R (1981) Seasonality of cardiovascular disease mortality and the possible protective effect of ultra-violet radiation. Int J Epidemiol 10, 337-341.

87. Scragg R (1995) Sunlight, vitamin D and cardiovascular disease. In Calcium-regulating Hormones and Cardiovascular Function, pp. 213-237. [MF Crass and LV Avioloi, editors]. Boca Raton, FL: CRC Press.

88. Simpson RU (1983) Evidence for a specific 1,25-dihydroxyvitamin $\mathrm{D}_{3}$ receptor in rat heart (abstract). Circulation $\mathbf{6 8}$, 239.

89. Weishaar RE \& Simpson RU (1987) Vitamin $\mathrm{D}_{3}$ and cardiovascular function in rats. J Clin Invest 79, 1706-1712.

90. Schmidt-Gayk H, Goossen J, Lendle F et al. (1977) Serum 25 -hydroxycalciferol in myocardial infarction. Atherosclerosis 26, 55-58.

91. Lund B, Badskjaer J, Lund B et al. (1978) Vitamin D and ischaemic heart disease. Horm Metab Res 10, 553-556.

92. Vik T, Try K, Thelle DS et al. (1979) Tromso Heart Study: vitamin D metabolism and myocardial infarction. Br Med J 2, 176.

93. Scragg R, Jackson R, Holdaway IM et al. (1990) Myocardial infarction is inversely associated with plasma 25-hydroxyvitamin $\mathrm{D}_{3}$ levels: a community-based study. Int J Epidemiol 19, 559-563.

94. Marniemi J, Alanen E, Impivaara O et al. (2005) Dietary and serum vitamins and minerals as predictors of myocardial infarction and stroke in elderly subjects. Nutr Metab Cardiovasc Dis 15, 188-197.

95. Wang TJ, Pencina MJ, Booth SL et al. (2008) Vitamin D deficiency and risk of cardiovascular disease. Circulation 117, 503-511.

96. Giovannucci E, Liu Y, Hollis BW et al. (2008) 25-Hydroxyvitamin D and risk of myocardial infarction in men: a prospective study. Arch Intern Med $\mathbf{1 6 8}$, 1174-1180.
97. Melamed ML, Michos ED, Post W et al. (2008) 25-Hydroxyvitamin D levels and the risk of mortality in the general population. Arch Intern Med 168, 1629-1637.

98. Kilkkinen A, Knekt P, Aro A et al. (2009) Vitamin D status and the risk of cardiovascular disease death. $A m J$ Epidemiol 170, 1032-1039.

99. Pilz S, Dobnig H, Nijpels G et al. (2009) Vitamin D and mortality in older men and women. Clin Endocrinol (Oxf) 71, 666-672.

100. Anderson JL, May HT, Horne BD et al. (2010) Relation of vitamin D deficiency to cardiovascular risk factors, disease status, and incident events in a general healthcare population. Am J Cardiol 106, 963-968.

101. Bolland MJ, Bacon CJ, Horne AM et al. (2010) Vitamin D insufficiency and health outcomes over $5 \mathrm{y}$ in older women. Am J Clin Nutr 91, 82-89.

102. Cawthon PM, Parimi N, Barrett-Connor E et al. (2010) Serum 25-hydroxyvitamin D, parathyroid hormone, and mortality in older men. J Clin Endocrinol Metab 95, 4625-4634.

103. Hutchinson MS, Grimnes G, Joakimsen RM et al. (2010) Low serum 25-hydroxyvitamin D levels are associated with increased all-cause mortality risk in a general population: the Tromso study. Eur J Endocrinol 162, 935-942.

104. Jassal SK, Chonchol M, von Muhlen D et al. (2010) Vitamin D, parathyroid hormone, and cardiovascular mortality in older adults: the Rancho Bernardo study. Am J Med 123, 1114-1120.

105. Michaelsson K, Baron JA, Snellman G et al. (2010) Plasma vitamin $\mathrm{D}$ and mortality in older men: a communitybased prospective cohort study. Am J Clin Nutr 92, 841-848.

106. Semba RD, Houston DK, Bandinelli S et al. (2010) Relationship of 25-hydroxyvitamin D with all-cause and cardiovascular disease mortality in older communitydwelling adults. Eur J Clin Nutr 64, 203-209.

107. Hsia J, Heiss G, Ren H et al. (2007) Calcium/vitamin D supplementation and cardiovascular events. Circulation 115, 846-854

108. Michos ED \& Blumenthal RS (2007) Vitamin D supplementation and cardiovascular disease risk. Circulation 115, 827-828.

109. Geleijnse JM (2011) Vitamin D and the prevention of hypertension and cardiovascular diseases: a review of the current evidence. Am J Hypertens 24, 253-262.

110. Burgaz A, Orsini N, Larsson SC et al. (2011) Blood 25-hydroxyvitamin D concentration and hypertension: a meta-analysis. J Hypertens 269, 211-218.

111. Targher G, Bertolini L, Padovani R et al. (2006) Serum 25-hydroxyvitamin $\mathrm{D}_{3}$ concentrations and carotid artery intima-media thickness among type 2 diabetic patients. Clin Endocrinol (Oxf) 65, 593-597.

112. Sugden JA, Davies JI, Witham MD et al. (2008) Vitamin D improves endothelial function in patients with type 2 diabetes mellitus and low vitamin D levels. Diabet Med 25, 320-325.

113. Witham MD, Dove FJ, Dryburgh M et al. (2010) The effect of different doses of vitamin D(3) on markers of vascular health in patients with type 2 diabetes: a randomised controlled trial. Diabetologia 53, 2112-2119.

114. Pittas AG, Lau J, Hu FB et al. (2007) The role of vitamin D and calcium in type 2 diabetes. A systematic review and meta-analysis. J Clin Endocrinol Metab 92, 2017-2029.

115. Mattila C, Knekt P, Mannisto S et al. (2007) Serum 25-hydroxyvitamin D concentration and subsequent risk of type 2 diabetes. Diabetes Care 30, 2569-2570.

116. Knekt P, Laaksonen M, Mattila C et al. (2008) Serum vitamin $\mathrm{D}$ and subsequent occurrence of type 2 diabetes. Epidemiology 19, 666-671. 
117. Forouhi NG, Luan J, Cooper A et al. (2008) Baseline serum 25-hydroxy vitamin $\mathrm{D}$ is predictive of future glycemic status and insulin resistance: the Medical Research Council Ely Prospective Study 1990-2000. Diabetes 57, 2619-2625.

118. Grimnes G, Emaus N, Joakimsen RM et al. (2010) Baseline serum 25-hydroxyvitamin D concentrations in the Tromso Study 1994-95 and risk of developing type 2 diabetes mellitus during 11 years of follow-up. Diabet Med 27, $1107-1115$.

119. Liu E, Meigs JB, Pittas AG et al. (2010) Predicted 25hydroxyvitamin D score and incident type 2 diabetes in the Framingham Offspring Study. Am J Clin Nutr 91, $1627-1633$.

120. Lindqvist PG, Olsson H \& Landin-Olsson M (2010) Are active sun exposure habits related to lowering risk of type 2 diabetes mellitus in women, a prospective cohort study? Diabetes Res Clin Pract 90, 109-114.

121. Jorde R \& Figenschau Y (2009) Supplementation with cholecalciferol does not improve glycaemic control in diabetic subjects with normal serum 25 -hydroxyvitamin D levels. Eur J Nutr 48, 349-354.

122. von Hurst PR, Stonehouse W \& Coad J (2010) Vitamin D supplementation reduces insulin resistance in South Asian women living in New Zealand who are insulin resistant and vitamin D deficient $-\mathrm{a}$ randomised, placebocontrolled trial. Br J Nutr 103, 549-555.

123. Alvarez JA \& Ashraf A (2010) Role of vitamin D in insulin secretion and insulin sensitivity for glucose homeostasis. Int J Endocrinol 351-385.

124. Reddy Vanga S, Good M, Howard PA et al. (2010) Role of vitamin D in cardiovascular health. Am J Cardiol 106, 798-805.

125. Autier P \& Gandini S (2007) Vitamin D supplementation and total mortality: a meta-analysis of randomized controlled trials. Arch Intern Med 167, 1730-1737.

126. Visser M, Deeg DJ, Puts MT et al. (2006) Low serum concentrations of 25-hydroxyvitamin $\mathrm{D}$ in older persons and the risk of nursing home admission. Am J Clin Nutr 84, 616-622.

127. Jia X, Aucott LS \& McNeill G (2007) Nutritional status and subsequent all-cause mortality in men and women aged 75 years or over living in the community. Br J Nutr $\mathbf{9 8}$, 593-599.

128. Semba RD, Houston DK, Ferrucci L et al. (2009) Low serum 25-hydroxyvitamin D concentrations are associated with greater all-cause mortality in older communitydwelling women. Nutr Res 29, 525-530.

129. Szulc P, Claustrat B \& Delmas PD (2009) Serum concentrations of $17 \beta-\mathrm{E}_{2}$ and 25-hydroxycholecalciferol (25OHD) in relation to all-cause mortality in older men the MINOS study. Clin Endocrinol (Oxf) 71, 594-602.

130. Anon. (1904) Obituary. Niels Ryberg Finsen. Lancet 2, 1036-1039.

131. Rollier A (1929) The sun cure and the work cure in surgical tuberculosis. BMJ 2, 1206-1207.

132. Dowling GB \& Prosser Thomas EW (1946) Treatment of lupus vulgaris with calciferol. Lancet 1, 919-922.

133. Boman HG (2003) Antibacterial peptides: basic facts and emerging concepts. J Intern Med 254, 197-215.

134. Liu PT, Stenger S, Li H et al. (2006) Toll-like receptor triggering of a vitamin D-mediated human antimicrobial response. Science 311, 1770-1773.

135. Gombart AF (2009) The vitamin D-antimicrobial peptide pathway and its role in protection against infection. Future Microbiol 4, 1151-1165.
136. Bartley J (2010) Vitamin D: emerging roles in infection and immunity. Expert Rev Anti Infect Ther 8, 1359-1369.

137. Gombart AF, Bhan I, Borregaard N et al. (2009) Low plasma level of cathelicidin antimicrobial peptide (hCAP18) predicts increased infectious disease mortality in patients undergoing hemodialysis. Clin Infect Dis $\mathbf{4 8}$, 418-424.

138. Nnoaham KE \& Clarke A (2008) Low serum vitamin D levels and tuberculosis: a systematic review and metaanalysis. Int J Epidemiol 37, 113-119.

139. Martineau AR, Honecker FU, Wilkinson RJ et al. (2007) Vitamin D in the treatment of pulmonary tuberculosis. J Steroid Biochem Mol Biol 103, 793-798.

140. Martineau AR, Timms PM, Bothamley GH et al. (2011) High-dose vitamin D(3) during intensive-phase antimicrobial treatment of pulmonary tuberculosis: a doubleblind randomised controlled trial. Lancet 377, 242-250.

141. Beard JA, Bearden A \& Striker R (2011) Vitamin D and the anti-viral state. J Clin Virol 50, 194-200.

142. McLeod JG, Hammond SR \& Hallpike JF (1994) Epidemiology of multiple sclerosis in Australia. With NSW and SA survey results. Med J Aust 160, 117-122.

143. van der Mei IA, Ponsonby AL, Dwyer T et al. (2003) Past exposure to sun, skin phenotype, and risk of multiple sclerosis: case-control study. BMJ 327, 316.

144. Munger KL, Levin LI, Hollis BW et al. (2006) Serum 25-hydroxyvitamin D levels and risk of multiple sclerosis. JAMA 296, 2832-2838.

145. Lucas RM, Ponsonby AL, Dear K et al. (2011) Sun exposure and vitamin D are independent risk factors for CNS demyelination. Neurology 76, 540-548.

146. Christakos S, Friedlander EJ, Frandsen BR et al. (1979) Studies on the mode of action of calciferol. XIII. Development of a radioimmunoassay for vitamin Ddependent chick intestinal calcium-binding protein and tissue distribution. Endocrinology 104, 1495-1503.

147. Norman AW, Frankel JB, Heldt AM et al. (1980) Vitamin D deficiency inhibits pancreatic secretion of insulin. Science 209, 823-825.

148. Zipitis CS \& Akobeng AK (2008) Vitamin D supplementation in early childhood and risk of type 1 diabetes: a systematic review and meta-analysis. Arch Dis Child 93, 512-517.

149. Cranney A, Horsley T, O'Donnell S et al. (2007) Effectiveness and safety of vitamin D in relation to bone health. Evid Rep Technol Assess (Full Rep) 1-235.

150. Chung M, Balk EM, Brendel M et al. (2009) Vitamin D and calcium: a systematic review of health outcomes. Evid Rep Technol Assess (Full Rep) 1-420.

151. Freedman DM, Looker AC, Chang SC et al. (2007) Prospective study of serum vitamin D and cancer mortality in the United States. I Natl Cancer Inst 99, 1594-1602.

152. Ginde AA, Scragg R, Schwartz RS et al. (2009) Prospective study of serum 25-hydroxyvitamin D level, cardiovascular disease mortality, and all-cause mortality in older US adults. J Am Geriatr Soc 57, 1595-1603.

153. Morabia A \& Costanza MC (2010) Vitamin D as in different. Prev Med 51, 195-196.

154. Rose G (1985) Sick individuals and sick populations. Int J Epidemiol 14, 32-38.

155. Bolland MJ, Avenell A, Baron JA et al. (2010) Effect of calcium supplements on risk of myocardial infarction and cardiovascular events: meta-analysis. BMJ 341, c3691.

156. Ish-Shalom S, Segal E, Salganik T et al. (2008) Comparison of daily, weekly, and monthly vitamin $\mathrm{D}_{3}$ in ethanol dosing protocols for two months in elderly hip fracture patients. J Clin Endocrinol Metab 93, 3430-3435. 